OPEN ACCESS

Edited by:

Jonas Schoelynck,

University of Antwerp, Belgium

Reviewed by:

Paulo Sergio Salomon,

Federal University of Rio de Janeiro,

Brazil

Xiufeng Zhang,

Jinan University, China

${ }^{*}$ Correspondence: Katrin Teubner

Katrin.Teubner@univie.ac.at

Specialty section:

This article was submitted to

Freshwater Science,

a section of the journal

Frontiers in Environmental Science

Received: 17 June 2020

Accepted: 17 August 2020

Published: 01 October 2020

Citation:

Teubner K, Teubner I, Pall K, Kabas W, Tolotti M, Ofenböck $T$ and Dokulil MT (2020) New Emphasis on

Water Transparency as Socio-Ecological Indicator for Urban Water: Bridging Ecosystem Service Supply and Sustainable Ecosystem Health. Front. Environ. Sci. 8:573724. doi: 10.3389/fenvs.2020.573724

\section{New Emphasis on Water} Transparency as Socio-Ecological Indicator for Urban Water: Bridging Ecosystem Service Supply and Sustainable Ecosystem Health

\author{
Katrin Teubner ${ }^{*}$, Irene Teubner ${ }^{2,3}$, Karin Pall ${ }^{4}$, Wilfried Kabas ${ }^{5}$, Monica Tolotti6, \\ Thomas Ofenböck ${ }^{7}$ and Martin T. Dokulil ${ }^{8}$
}

\begin{abstract}
1 Department of Functional and Evolutionary Ecology, Faculty of Life Sciences, University of Vienna, Vienna, Austria, ${ }^{2}$ Research Group Climate and Environmental Remote Sensing, Department of Geodesy and Geoinformation, TU Wien, Vienna, Austria, ${ }^{3}$ Climatology Section, Division Customer Service, Zentralanstalt für Meteorologie und Geodynamik, Vienna, Austria, ${ }^{4}$ Systema GmbH, Vienna, Austria, ${ }^{5}$ Department of Limnology and Bio-Oceanography, Faculty of Life Sciences, University of Vienna, Vienna, Austria, ${ }^{6}$ Department of Sustainable Agro-ecosystems and Bioresources, Research and Innovation Centre, Fondazione Edmund Mach, San Michele all'Adige, Italy, ${ }^{7}$ Municipal Department 45 - Water Management, Vienna City Administration, Vienna, Austria, ${ }^{8}$ Research Department for Limnology, Mondsee, University of Innsbruck, Mondsee, Austria
\end{abstract}

The perspective on water transparency changed since the early days of limnology from being a physical parameter of optical water property to an ecological indicator tracking algal turbidity due to eutrophication or an overall success of sustained lake restoration in the late 60ies to 80ies. In modern cities, where ecosystems are commonly deteriorated by man-made modifications, water transparency offers a great opportunity to the public to raise socio-ecological consciousness concerning urban green-blue spaces. We thus re-emphasize water transparency as a key indicator of multi-functional value when assessing an oxbow lake of the riverine floodplain in Vienna, the Alte Donau. Our study covers the eutrophication from 1987 to 1994 due to the inclusion of the riverine landscape in the urban area, the following lake restoration with an ecosystem shift from a nutrient-rich, algal-turbid water body to a nutrientpoor, clear-water macrophyte controlled system and the impact of global warming in recent decades. We used light attenuation profiles to identify depth layers of specific ambient light requirements for photosynthetic domains (phytoplankton and submerged macrophytes), and to interpret Secchi measurements. Here, we calculated the depth at $1 \%$ (minimum light requirements for phytoplankton growth as euphotic depth), 3\% (minimum light requirements for macrophytes as maximum macrophyte colonization depth), and 12\% (preferred light requirements for phytoplankton development) of surface ambient light. A Secchi disk water transparency of $1.5 \mathrm{~m}$ ("lake bottom view"), judged as good water quality by human perception, refers to mesotrophic conditions with a maximum colonization depth for macrophytes exceeding the mean lake depth in Alte Donau. Water clarity required for sustained macrophyte growth, in particular for favoring bottom-dwelling Chara meadows instead of tall-growing Myriophyllum spicatum, is 
$3.5 \mathrm{~m}$ Secchi depth and thus exceeds by far water clarity requested due to bathing aesthetics. Global warming, mirrored by an advanced warming in spring seems to favor significantly a higher yield of macrophytes mainly built up by Myriophyllum at the expense of the yield of algae. The prolongation of the summer period above $21^{\circ} \mathrm{C}$, however, coincides with lowered Secchi transparency. Water visibility during the hot season thus seems to be slightly hampered against lake restoration efforts by global warming.

Keywords: urban green-blue space, recreational lake area, oxbow lake restoration, Secchi depth, threshold light requirement, phytoplankton, aquatic plants, climate change

\section{INTRODUCTION}

Recent acceleration of man-made ecosystem degradation (Crutzen, 2002; Steffen et al., 2011; Dalby, 2016) became most obvious in urban areas. The greatest threats to urban floodplain in Vienna are represented by simplification of the ecosystem structure due to canalization (Sanon et al., 2012; Haidvogl et al., 2013; Hohensinner, 2019), biodiversity loss (e.g., Tockner and Schiemer, 1997; Funk et al., 2009; Hein et al., 2016), and overusing natural systems for recreation purposes (e.g., Arnberger and Eder, 2012). Shortcomings of deteriorated surface waters were not only of concern from an ecological perspective but also raised social awareness in modern urban live. On the one hand, urban waters are at risk of being destroyed due to human impact on the other hand they are important for improving life quality in metropolitan areas (e.g., Naselli-Flores, 2008; Zimmermann-Timm and Teubner, 2019). Urban development thus recently gained an increasing awareness of the potential of green and blue infrastructure for the quality-of-life in densely populated areas. Aquatic ecosystems that originally were part of river floodplains in the vicinity of cities thus came to the fore of sustainable management practices (Funk et al., 2009; Sanon et al., 2012; Haidvogl et al., 2013; Preiner et al., 2018). They became more and more attractive serving by a multitude of cultural ecosystem services beneficial for quality-of-life in the city (Kazmierczak and Carter, 2010; Völker and Kistemann, 2011; Keeler et al., 2012; Dou et al., 2017; Hozang, 2018). Aesthetic satisfaction with nature in green and blue space experienced an increasing popularity contributing to higher awareness of life quality in urban areas (e.g., Smith et al., 1991, 1995a; Völker and Kistemann, 2011; Tajima, 2012; Kabisch, 2015; Kati and Jari, 2016; Dou et al., 2017; Lee, 2017; Angradi et al., 2018).

Despite the existence of a complex scientific assessment for urban waters (e.g., Karr, 1991; Dokulil and Teubner, 2002; Schneider and Melzer, 2003; Istvánovics et al., 2007; Hering et al., 2010; Janecek et al., 2018; Teubner et al., 2018b), human perception judging a good or sufficiently good status to be of high recreational value is often reduced to at least a single characteristic: the water transparency. The colloquial meaning of the term "good water quality" for Viennese is "a water body with high water transparency." When judging the suitability of an urban water body for multitude recreational use, the water transparency is often the primary optical criterion of human perception (Smith et al., 1991, 1995a; Michael et al., 1996; Wilson and Carpenter, 1999; Gibbs et al., 2002; Völker and Kistemann, 2011; Keeler et al., 2012; Angradi et al., 2018), followed by color (Smith et al., 1995b), and odor (Ginzburg et al., 1998; Chorus et al., 2000; Dokulil and Teubner, 2000; Paerl et al., 2001; Graham et al., 2010). In addition, aspects of urban landscape planning of water banks and associated green spaces enhancing nature aesthetics and better microclimate conditions play a further role (e.g., Bulkley and Mathews, 1974; Kazmierczak and Carter, 2010; Völker and Kistemann, 2011; Hozang, 2017; Lee, 2017). The perception of clear-water is further linked to hedonic values (e.g., West et al., 2016) as e.g., the believe in a pleasant and healthy environment. The trust in water clarity follows an intrinsic instinct to minimize health risk from unpleasant ill-making water as this came true for surface waters known from historical records when cities were rather seen as unhealthy places. The history of the role of polluted water and associated diseases for capital city Vienna are in detail described in Haidvogl (2019).

Measuring water transparency by disk visibility goes back to 1815 , when it was adopted for measurements in the ocean and not lakes. This method yielded greater attention by the disk experiments published by Secchi (1866) (e.g., Aarup, 2002; Täuscher, 2015), i.e., just before the freshwater science epoch was initiated by Forel (1841-1912), who established limnology as a new branch of science in 1892 (Vincent and Bertola, 2012). Individual measurements of Secchi disk transparency in freshwaters may vary substantially from only few centimeters in hypertrophic riverine lakes (e.g., Teubner et al., 1999) to far more than $20 \mathrm{~m}$ in pristine alpine lakes (report of extreme high Secchi visibility of up to $26.5 \mathrm{~m}$ in the Alps; e.g., Tolotti and Cantonati, 2000; Tolotti, 2001).

In ecological research, measuring water transparency went beyond the physics of visibility of a water body and evolved into a tool for ecosystem assessment. It became of particular interest when eutrophication and the associated water turbidity due to algal blooms obviously deteriorated the ecosystems in the Anthropocene. Early trophic classification of lakes focused on the response of algal growth to the nutrient surplus by eutrophication, i.e., mainly phosphorus, which are well known as Vollenweider models (e.g., Vollenweider, 1968). Trophic classifications schemes by other studies were expanded to link an increasing amount of nutrient yield, such as algal biomass, with gradual deterioration of water clarity (e.g., Forsberg and Ryding, 1980; Nürnberg, 1996; ÖNORM M6231, 2001; Håkanson et al., 2005). In turn, in view of lake restoration, the sustainable increase of Secchi 
disk transparency - or also mentioned as water clarity became the most well attributed value to water quality by human perception. It thus offered a key target indicating an overall success of lake restoration (e.g., Meijer et al., 1999; Hilt et al., 2006; Søndergaard et al., 2007; Gulati et al., 2008; Dokulil et al., 2018).

Although water transparency may differ among waters due to the natural color or inorganic seston, it is usually higher for ecosystems close to natural reference conditions hosting species assemblages that are characterized as reference biota. Such ecosystems are not strongly modified by manmade surplus of nutrients or other pollutants (man-made deterioration of water see e.g., Hupfer and Kleeberg, 2007; Dokulil and Teubner, 2011; Zimmermann-Timm and Teubner, 2019) so that their high transparency indicate a high degree of ecological integrity or ecosystem health from an ecological point of view (Karr, 1991; Dokulil and Teubner, 2002; Hering et al., 2010; Teubner et al., 2018b). Urban lake and river restoration today, however, does not end up with a good "water quality delivery" but focuses on securing a better "well-being" by providing valuable ecosystem services in particular if shared by socio-ecological awareness in cities. Even if the term Anthropocene was formulated as a warning of accelerated deterioration of ecosystems by recent human activities worldwide (Dalby, 2016), new attempts of "bettering the world" from regional to global scale are discussed. Thus, identifying ecosystem services generated in urban areas or in the vicinity of settlements has drawn increasing attention in recent time (e.g., Bolund and Hunhammar, 1999; Yigitcanlar et al., 2008; Sanon et al., 2012; Hein et al., 2016; Boyer et al., 2019).

The emphasis on water clarity in our study is exemplified for Alte Donau as it is the most well studied urban lake in the capital city of Austria, Vienna. The ecosystem faced dramatic changes mainly by losing its natural connectivity from the main river during river regulation from 1868 onward. The oxbow lake suffered from enhanced eutrophication from 1987 to 1994 due to the degradation of the riverine landscape into urban areas and global warming in recent decades. The growing public awareness of threats by eutrophication and global warming for providing reliable and sustainable provisioning of cultural ecosystem services (e.g., bathing, boating, and recreational fishing) called for a sustainable restoration of this Viennese oxbow lake in 1994. The progress of the restoration, which spanned more than 20 years and consisted of three main treatment periods characterized by various measures of sustainable restoration and ecological based activities, is summarized in Dokulil et al. (2018). We want to put here new emphasis on water transparency aimed at answering the question whether water transparency holds true as socio-ecological key indicator for Alte Donau. We want to understand how suffice the water clarity can be for identifying ecosystem services in view of (1) suitability for recreational use and (2) the overall success of sustained lake restoration. In addition, we will explore (3) the impact of global warming superimposing "water clarity mediated" ecosystem services.

\section{MATERIALS AND METHODS}

\section{Site Description}

The study area Alte Donau refers to the Vienna Basin, part of the northwest margin of the Pannonian Plain in Central Europe. The oxbow lake is located in the suburban area "Donaufeld" in Vienna, the capital of Austria (map and photos in Figure 1). The main characteristics of this urban lake given in Table 1 includes information about location, genesis, morphometry, trophic state in 1987 and 1992-2019 as well as mean annual air temperature in the suburban and urban neighborhood. In addition, the restoration measures from 1995 to 2019 are summarized. Samples analyzing plankton biota and chemistry were taken in the two main impoundments at biweekly (to monthly) intervals. Further details are available about morphometry (Kum and Dokulil, 2018), chemistry (Donabaum and Riedler, 2018), phytoplankton (Teubner et al., 2018b), primary production (Dokulil and Kabas, 2018), zooplankton (Teubner et al., 2018a), macrophytes (Pall, 2018), fish (Waidbacher and Silke-Silvia Drexler, 2018), and urban planning (Hozang, 2018).

\section{Measuring Water Transparency}

Water transparency was regularly measured with a white Secchi disk at biweekly (to monthly) intervals from 1993 to 2019. Secchi depth $\left(z_{\text {Secchi }}\right)$ measurements were conducted far from stands of underwater vegetation and thus relate to the "open water" of the lake. In order to extend this parameter to the early survey period (1987-1992), Secchi disk transparency was estimated based on Chl- $a$ and TP measurements, which cover the period 1987-1995. This provides an overlap period of 3 years for deriving the relationship between Secchi disk reading and Chl- $a$ and TP measurements.

In addition to regular Secchi disk transparency, the underwater light attenuation was retrieved from underwater light profile measurements of Photosynthetically Active Radiation (PAR) with a $4 \pi$ quantum sensor (LI-COR) for 7 years (1995-2001), which covers the period between the restoration launching and first re-establishment of macrophytes. The mean vertical attenuation coefficient $\left(k_{P A R}\right)$ is shown as mean values in Table 2.

The euphotic depth $\left(z_{e u}\right)$, defined as the water layer from the lake surface ( $100 \%$ light) down to the depth of $1 \%$ underwater light intensity, where photosynthesis exceeds respiration, was calculated from the vertical $k_{P A R}$ as follows:

$$
z_{e u}=\frac{(\ln 100-\ln 1)}{k_{P A R}}=\frac{4.605}{k_{P A R}}
$$

Minimum light requirement for macrophytes refers to the mean of 2 and $4 \%$ of surface ambient light, according to Dennison et al. (1993) and Middelboe and Markager (1997), respectively. The maximum depth satisfying light requirements for macrophyte growth $\left(z_{\text {macrophytes }}\right)$ at 3\% underwater light intensity is calculated as:

$$
z_{\text {macrophytes }}=\frac{(\ln 100-\ln 3)}{k_{P A R}}=\frac{3.507}{k_{P A R}}
$$

On calm days, summer phytoplankton biomass is often heterogeneously distributed along the vertical profile as long as 

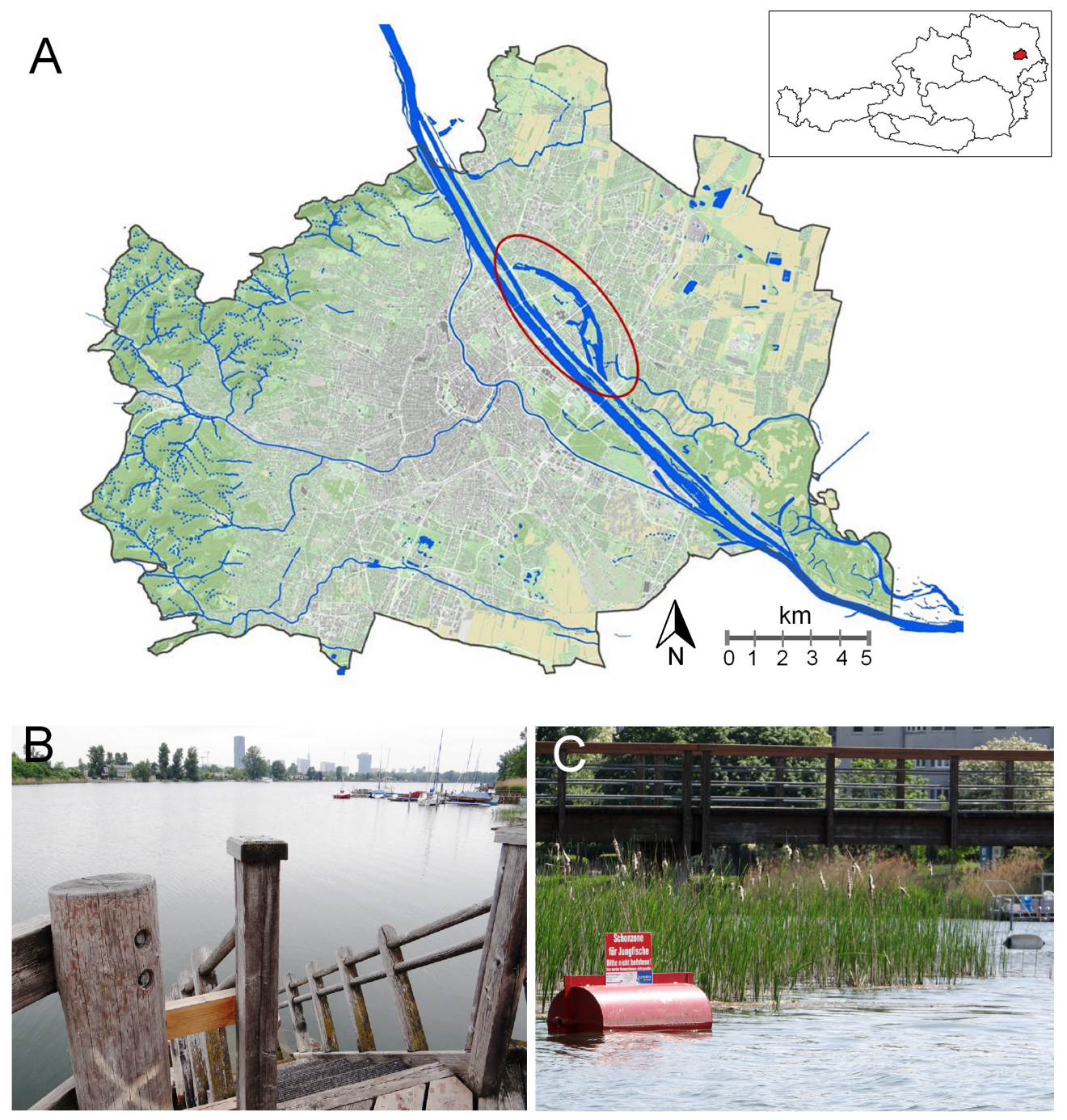

FIGURE 1 | Alte Donau- tightly coupled urban settlement and nature space. (A) Water city map Vienna. The ellipse indicates the oxbow-lake Alte Donau, in the close neighborhood of Neue Donau and the Danube River. Inset: Country map of Austria with Vienna (marked red). (Data source: City of Vienna - https://data.wien.gv.at; Inset: created using data from https://www.data.gv.at/katalog/dataset/bev_verwaltungsgrenzenstichtagsdaten150000). (B) Elongated impoundment shape due to the former main stretch of the Danube River. Reed belts (Phragmites australis in association with other reed belt plants) were re-planted on both banks. Use of cultural ecosystem services are indicated by boats and public wooden bathing platforms providing access to the open water for free. (C) Littoral area protected for young fish, close to a lake bank with urban settlements. Buoy reminds visitors by swimming or boat to stay away respecting nature. Sign with words "Schonzone für Jungfische. Bitte nicht befahren. Hier werden Wasserpflanzen nicht gemäht." (B-C) taken in 2015, from www.lakeriver.at.

no strong turbulences occur in the epilimnion. Particle clouds of summer phytoplankton in a rather narrow horizontal layer below lake surface build an epilimnetic maximum. This epilimnetic layer in mesotrophic lakes is most commonly found at a depth of $12 \%$ light intensity (Teubner et al., 2004). The depth of epilimnetic phytoplankton biomass peak $\left(z_{\text {peak-phyto }}\right)$ is thus calculated as follows:

$$
z_{\text {peak-phyto }}=\frac{(\ln 100-\ln 12)}{k_{P A R}}=\frac{2.120}{k_{P A R}}
$$

The factor $f_{e u}$ with $f_{e u}=\frac{z_{e u}}{z_{\text {Sechi }}}$ can be used to retrieve euphotic depth from Secchi measurements by multiplying the factor with Secchi disk readings.
Similarly, multiplying the factors $f_{\text {macrophytes }}$ and $f_{\text {peak-phyto }}$ with $z_{\text {Secchi }}$, the deepest layer for macrophyte growth $z_{\text {macrophytes }}$ (maximum colonization depth for macrophytes defined by $3 \%$ light availability) and the depth of peak phytoplankton $z_{\text {peak-phyto }}$ (depth of phytoplankton biomass peak layer defined by $12 \%$ light availability) is derived, respectively.

The percentage of surface ambient light at Secchi depth $\left(I_{Z_{\text {Secchi }}}\right)$ is:

$$
I_{Z_{\text {Sech }}}=e^{\left(\ln 100-k_{P A R} \times z_{S e c h i}\right)}=100 e^{-k_{P A R} \times z_{\text {Sech }} i}
$$

The decreasing $z_{\text {Secchi }}$ due to increasing $k_{P A R}$ in Alte Donau is described by the equation $z_{\text {Secchi }}=1.40 / k_{P A R}$ for individual 
TABLE 1 | Main characteristics of oxbow lake Alte Donau in Vienna.

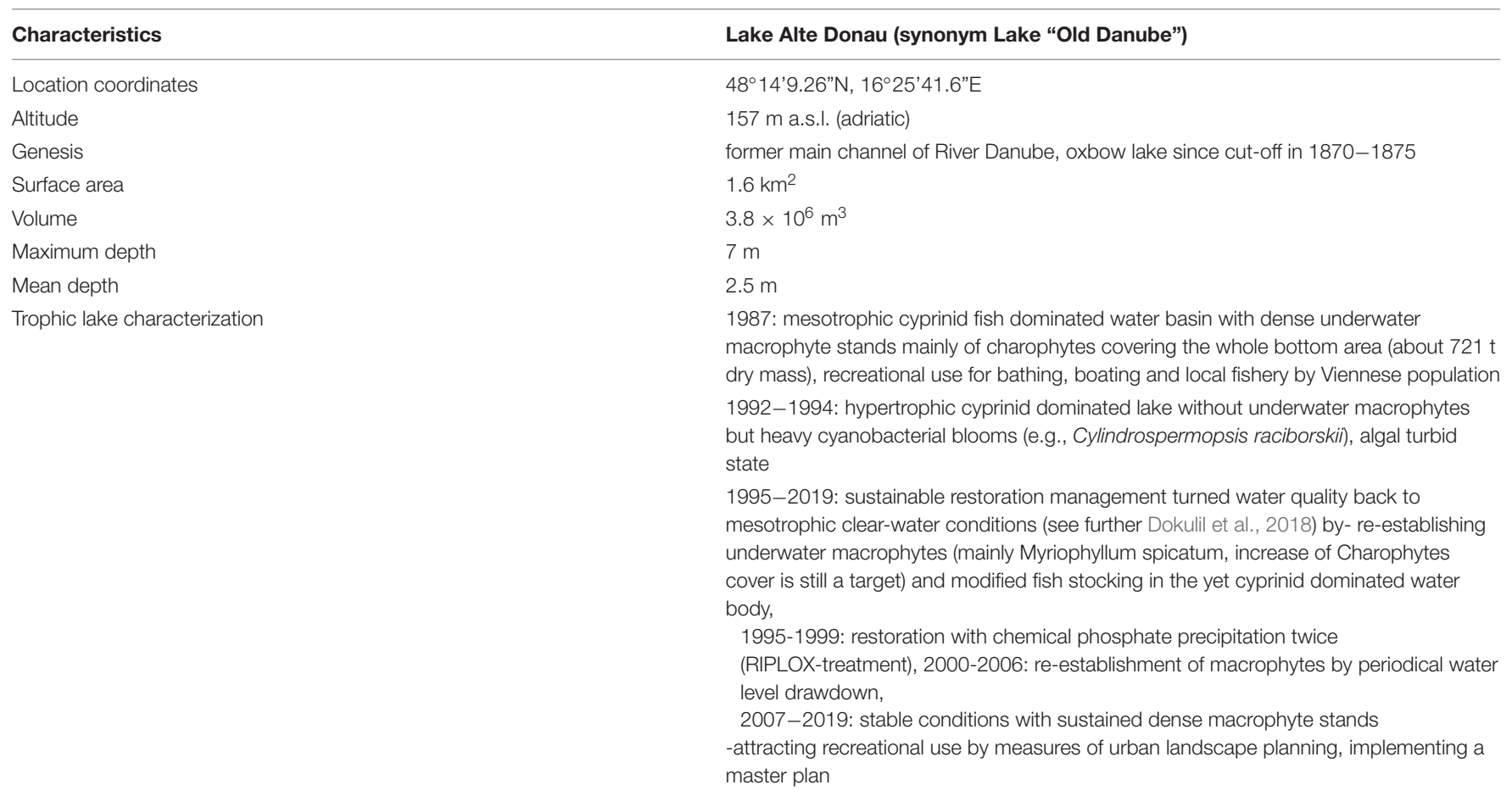

Annual air temperature Wien-Donaufeld*, suburb in Vienna (closest distance to $11.6^{\circ} \mathrm{C}(10.3-12.7)$

Alte Donau 1.6 km, to River Danube 3.1 km) (mean 2005-2018)

Annual air temperature Wien-Innere Stadt*, Vienna city centre (closest distance $12.5^{\circ} \mathrm{C}(11.1-13.5)$

to Alte Donau 5.2 km, to River Danube 4.2 km) (mean 2005-2018)

Difference in annual air temperature between Wien-Innere Stadt and

Wien-Donaufeld

mean: $0.9^{\circ} \mathrm{C}(\max : 1.1, \min : 0.8)$

*Data from ZAMG and Jahrbuch (2020).

measurements $\left(n=131, \mathrm{R}^{2}=0.55, p<0.001\right)$ (c.f., Megard and Berman, 1989). Averaged values of optical properties as $1 \%, 3 \%$ and $12 \%$ surface light depths, factor predicting euphotic zone from Secchi depth, the percentage of ambient light at Secchi depth (\%) and related parameters are shown in Table 2.

\section{Statistical Treatment}

Data in Table $\mathbf{3}$ and Figures 2-8 are based on the original dataset of biweekly sampling. However, as sampling was not always carried out in exactly 2 -week intervals, available data were interpolated at daily resolution (Livingstone, 2003; Sapna et al., 2015) and were averaged afterward over a 2week period (Figure 3). These bi-weekly data were then used to calculate annual averages (in Figure 2 for Secchi, Figure 4). This avoids biases in the averages due to a more frequent sampling in summer and a relatively less frequent sampling in winter. Furthermore, the interpolated daily data were also used to retrieve the Julian day of onset about a certain value of water surface temperature (WT) and the length of the warm period, i.e., the number of days each year with WT above a certain value (data matrix for Figures 5-8 and Table 3). Despite the normal distribution for most of the temperature data, the respective trends of the year-to-year variation were calculated as robust trend lines by non-parametric fitting according to Theil (1950) as described in Helsel and Hirsch (2002). These robust trend lines are applied to calculate the reliable slope of the yearto-year trends (Figures 5A, 6A, 8 and Table 3), which are robust against outliers of unusual high or low values in the first or last year of observation. The statistical significance of the trends is calculated by Mann-Kendall tests using $\mathrm{R}$ (McLeod, 2015).

Most of the robust trend lines for the year-to-year variations of the length of warm period or for the earlier onset of passing a certain temperature value were statistically significant (black bars in Figures 5A, 6A). Therefore, data were detrended before correlation analysis (anomalies used in Figures 5B-D, 6B-D, 7). Furthermore, significant robust trends were found for year-to-year variation of other parameters such as Secchi disk transparency, bathing visits per population, and thus anomalies were also calculated before analyzing the correlation of year-to-year variations between respective variables. The linearly detrending of time series data prior to correlation analysis is done to avoid spurious relationships, which might occur only due to the presence of significant trends.

Further, prior to the statistical correlation analysis shown in Figures 5B-D, 6B-D, 7, data were tested for normal distribution 
TABLE 2 | Optical water properties as Secchi disk transparency $\left(z_{\text {Secchi }}\right)$, the percentage of surface ambient light at $z_{\text {Secchi }}\left(I_{Z_{\text {Sechi }}}\right)$ and the underwater light attenuation $\left(k_{P A R}\right)$ satisfying light requirements for photosynthesis of phytoplankton and macrophytes and human perception to judge water suitability for bathing (satisfying water clarity for recreational aesthetics).

\begin{tabular}{|c|c|c|c|c|c|c|c|c|c|c|c|}
\hline \multirow[t]{2}{*}{ Category } & \multirow[t]{2}{*}{ (A) all } & \multicolumn{4}{|c|}{ (B) Seasonal development } & \multicolumn{3}{|c|}{ (C) Trophic lake classification scheme } & \multicolumn{3}{|c|}{ (D) Human water-quality perceptions for bathing } \\
\hline & & Spring & Summer & Autumn & Winter & Oligo-trophic & Meso-trophic & Eu-trophic & $z_{\text {Secchi }}>1.55 \mathrm{~m}$ & $z_{\text {Secchi }} 1.45-1.55 \mathrm{~m}$ & $z_{\text {Secchi }}<1.45 \mathrm{~m}$ \\
\hline$z_{\text {Secchi }}[\mathrm{m}]$ & 1.62 & 1.75 & 1.36 & 1.56 & 2.3 & 2.45 & 1.72 & 1.17 & 2.07 & 1.50 & 1.17 \\
\hline$I_{Z_{\text {Secchi }}}[\%]$ & 26 & 27 & 28 & 24 & 21 & 21 & 26 & 28 & 23 & 25 & 29 \\
\hline$k_{P A R}\left[\mathrm{~m}^{-1}\right]$ & 0.918 & 0.796 & 0.981 & 1.012 & 0.802 & 0.728 & 0.838 & 1.149 & 0.747 & 0.934 & 1.096 \\
\hline$z_{e u}[\mathrm{~m}]$ & 5.35 & 6.04 & 4.93 & 4.82 & 6.2 & 6.62 & 5.72 & 4.18 & 6.33 & 5.02 & 4.40 \\
\hline$f_{\text {eu }}$ & 3.45 & 3.58 & 3.65 & 3.24 & 2.99 & 3.05 & 3.42 & 3.62 & 3.17 & 3.35 & 3.78 \\
\hline$z_{\text {macrophytes }}[\mathrm{m}]$ & 4.08 & 4.60 & 3.75 & 3.67 & 4.83 & 5.04 & 4.36 & 3.19 & 4.82 & 3.82 & 3.35 \\
\hline$f_{\text {macrophytes }}$ & 2.63 & 2.73 & 2.78 & 2.48 & 2.28 & 2.32 & 2.60 & 2.76 & 2.42 & 2.55 & 2.88 \\
\hline$z_{\text {peak-phyto }}[\mathrm{m}]$ & 2.47 & 2.78 & 2.27 & 2.22 & 2.92 & 3.05 & 2.64 & 1.93 & 2.91 & 2.31 & 2.03 \\
\hline$f_{\text {peak-phyto }}$ & 1.59 & 1.65 & 1.68 & 1.49 & 1.38 & 1.41 & 1.58 & 1.67 & 1.46 & 1.54 & 1.74 \\
\hline Chl-a $\left[\mu \mathrm{g} \mathrm{L}^{-1}\right]$ & 10 & 7.5 & 11 & 12.5 & 5.9 & 3.1 & 7.7 & 17 & 6.6 & 11 & 13 \\
\hline$n$ & 131 & 38 & 43 & 37 & 13 & 11 & 82 & 38 & 55 & 16 & 60 \\
\hline
\end{tabular}

Depth of surface ambient light at 1\% refers to minimum light requirements of phytoplankton (euphotic depth, zeu), at 3\% to minimum light requirements of submerged

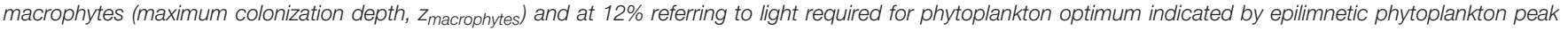

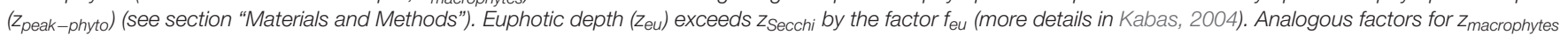

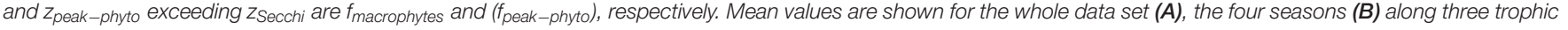

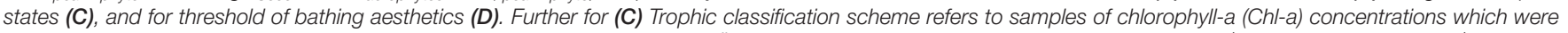

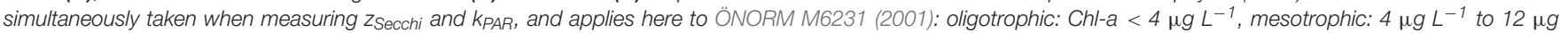

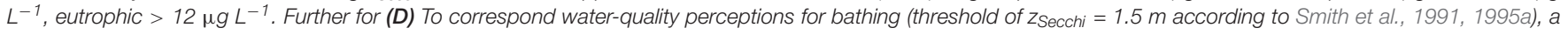

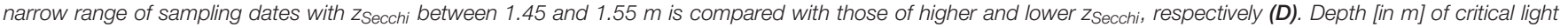

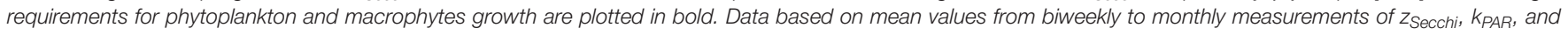
Chl-a, in Alte Donau (1995-2001, $n=131)$.

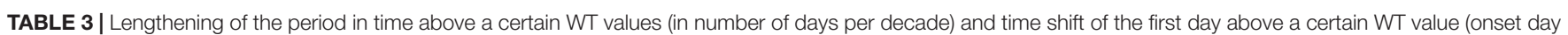
shifted per decade) calculated from slopes of robust trend lines covering measurements from 1987 to 2019.

\begin{tabular}{|c|c|c|c|c|c|c|c|c|c|c|c|c|c|c|c|c|c|c|c|}
\hline WT $\left[{ }^{\circ} \mathrm{C}\right]$ & 5 & 6 & 7 & 8 & 9 & 10 & 11 & 12 & 13 & 14 & 15 & 16 & 17 & 18 & 19 & 20 & 21 & 22 & 23 \\
\hline $\begin{array}{l}\text { Lengthening of } \\
\text { period [increasing nb of } \\
\text { days per decade] }\end{array}$ & 0 & 3.6 & $4.5^{\star}$ & $4.6^{\star}$ & $5.9^{\star \star}$ & $5.8^{\star \star \star}$ & $6.1^{\star \star \star}$ & $5.4^{\star \star \star}$ & $4.1^{\star \star}$ & $5.4^{\star \star}$ & $5.2^{*}$ & $6.5^{\star \star}$ & $6.4^{\star \star}$ & $6.6^{\star \star}$ & $7.2^{\star \star}$ & $8.7^{\star \star \star}$ & $12.5^{\star \star \star}$ & $14.7^{\star \star \star}$ & $18^{\star \star \star}$ \\
\hline $\begin{array}{l}\text { Length of period in } 1987 \\
\text { [nb of days] }\end{array}$ & 245 & 245 & 227 & 220 & 203 & 196 & 184 & 176 & 169 & 158 & 149 & 136 & 122 & 104 & 94 & 79 & 53 & 35 & 7 \\
\hline $\begin{array}{l}\text { Length of period in } 2019 \\
\text { [nb of days] }\end{array}$ & 256 & 257 & 243 & 237 & 226 & 216 & 206 & 196 & 183 & 176 & 167 & 158 & 144 & 133 & 120 & 109 & 97 & 87 & 71 \\
\hline $\begin{array}{l}\text { Timing shift for onset [shift } \\
\text { earlier per decade in nb of } \\
\text { days] }\end{array}$ & -0.4 & -1.8 & -2.7 & -3.2 & $-3.8^{\star}$ & $-4.5^{\star \star}$ & $-4.5^{\star \star}$ & $-4.5^{\star \star \star}$ & $-4.0^{\star *}$ & $-4.2^{\star \star \star}$ & $-3.8^{\star \star}$ & $-4.5^{\star \star}$ & $-5.2^{\star}$ & -3.8 & -3.5 & $-6.3^{*}$ & $-6.4^{\star \star}$ & $-9.5^{\star \star \star}$ & $-7.1^{\star}$ \\
\hline Onset day in 1987 [JD] & 63 & 76 & 86 & 93 & 100 & 105 & 105 & 116 & 118 & 122 & 126 & 116 & 135 & 140 & 147 & 159 & 164 & 176 & 175 \\
\hline Onset day in 2019 [JD] & 61 & 70 & 76 & 81 & 86 & 89 & 89 & 100 & 104 & 108 & 112 & 100 & 117 & 126 & 135 & 137 & 142 & 175 & 149 \\
\hline
\end{tabular}

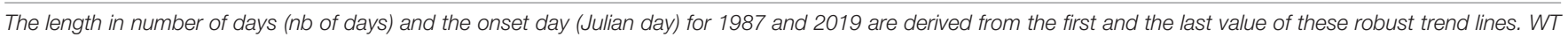
values from $5^{\circ} \mathrm{C}$ to $23^{\circ} \mathrm{C}$ as in Figures 5, 6. Significance of trends are marked by ${ }^{*} p<0.05,{ }^{* *} p<0.01,{ }^{* *} p<0.001 ; n b$, number.

and passed the Shapiro-test (Dunn and Clark, 1974) for satisfying Pearson correlation.

For analyzing climate response, the North Atlantic Oscillation (NAO) Index was used as climate signal since it represents a common proxy for studying the climate impact on aquatic ecosystems in the temperate zone (NAO station-based, from Hurrell, 2020 eds). A first testing of various seasonal NAO indices indicated the NAO signal for the period December March $\left(\mathrm{NAO}_{D J F M}\right.$, see Figures 5-7) as most suitable. This winter climate signal does not vanish as fast as the NAO signal of later months or seasons (see, e.g., Blenckner et al., 2007; Dokulil et al., 2010); thus, it is suitable for unraveling the climate response in late spring-early summer in Alte Donau (see also Teubner et al., 2018b).

\section{RESULTS}

Urban oxbow lake Alte Donau is embedded in a naturally landscaped parkland. Visiting Alte Donau located in the suburban area of Vienna (Figure 1A), the manifold popular uses become obvious. Among the cultural ecosystem services provided recreational activities are common such as bathing in public baths or at publicly available wooden walkways along the lake banks 

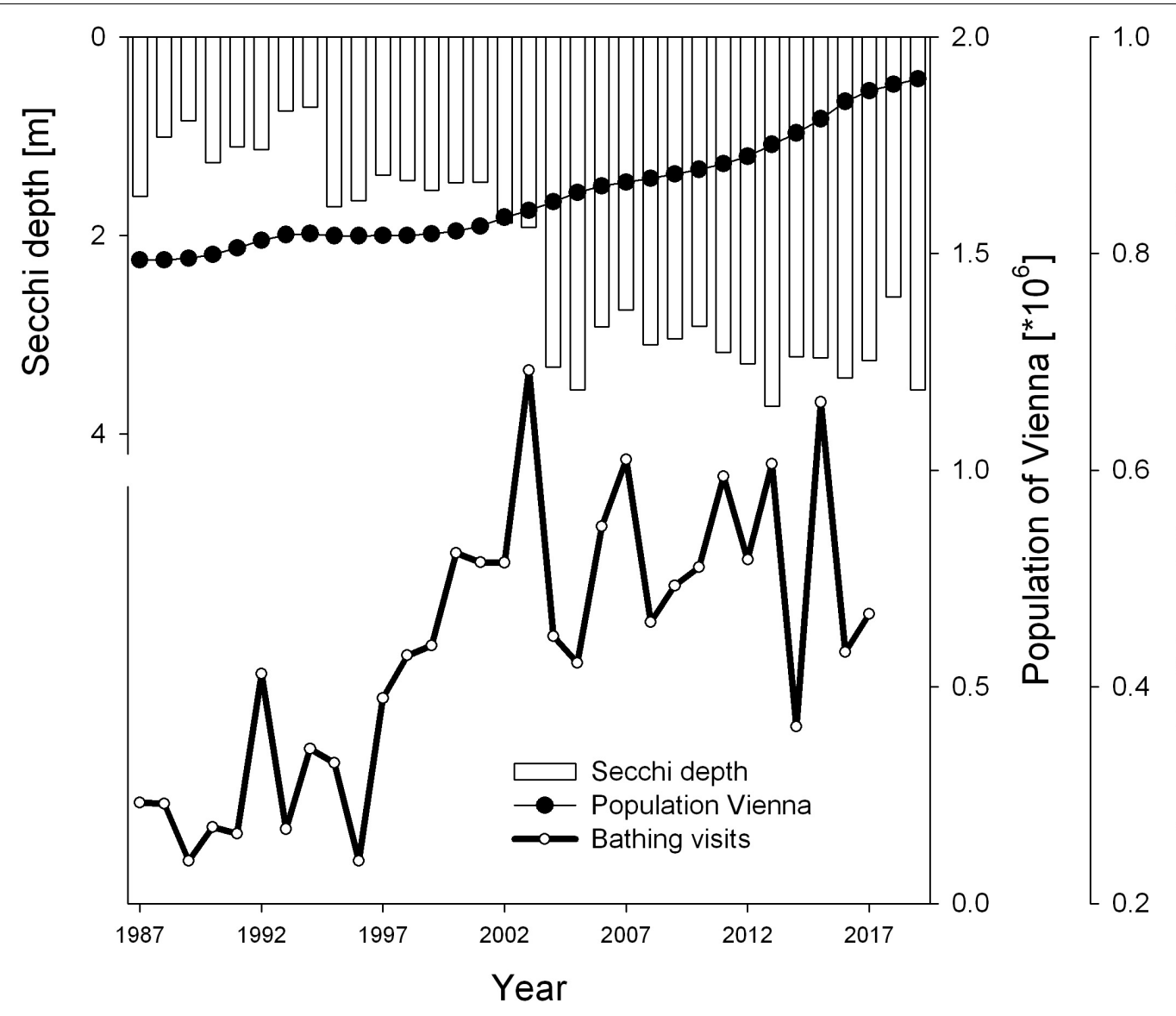

FIGURE 2 | Population development of capital city Vienna and water transparency as annual Secchi depth of Alte Donau for years 1987-2019. The number of annual bathing visits per annual population of Vienna are from 1987 to 2017 (data for population from www.statistik.at, for annual bathing visits from Hozang, 2017).

(Figure 1B), sport fishing, sport boating (rowers, sailors, and recreational fun boats), walking and cycling on the lake shore, visiting the playgrounds, recreational sport grounds, lawns and restaurants. Reed belts are naturally covering the shoreline or have been replanted (Figure 1C).

The population growth from 1.48 to 1.90 million inhabitants over the recent 33-year study period is shown in Figure 2. The highest numbers of bathing visits were observed in 2003 and 2015 (1.1 and 1.2 million, respectively), the lowest numbers in 1989 and 1996 (0.36 and 0.37 million, respectively; data from Hozang, 2017). The number of bathing visits per population of Vienna is displayed in Figure 2. These relative bathing visits also significantly increased from 0.29 in 1987 to 0.47 in 2017 following a robust increasing trend $(p<0.05)$. The water transparency, as represented by Secchi disk measurements, increased significantly over the 33 years of observation, with lowest annual means of 0.9 $\mathrm{m}$ and $1.0 \mathrm{~m}$ in 1993 and 1994, respectively (Figure 2). Starting in 1995, the first year of restoration, annual Secchi depth exceeded $1.5 \mathrm{~m}$ and increased further to highest values above $3.5 \mathrm{~m}$ from 2005 to 2016 and in 2019.

A water clarity corresponding to Secchi disk transparency of $1.5 \mathrm{~m}$ and higher is often considered as minimum threshold satisfying bathing aesthetics in view of human perception (Smith et al., 1991, 1995a). According to our observations in Alte Donau, a $z_{\text {Secchi }}$ of $1.5 \mathrm{~m}$ corresponds to a penetration of $25 \%$ surface ambient light (Table 2). Applying this water clarity threshold of bathing aesthetics to Alte Donau, the corresponding chlorophyll$a$ concentration (Chl- $a$ ) would be about $11 \mu \mathrm{g} \mathrm{L}^{-1}$ (Table 2) and thus refers to a water quality of the mesotrophic state (Chl- $a$ limits indicating mesotrophic state refer to $>4 \mu \mathrm{g} \mathrm{L}^{-1}$ and $<12 \mu \mathrm{g} \mathrm{L}^{-1}$ according to ÖNORM M6231, 2001; see also Teubner et al., 2018b). According to Table 2, with $z_{\text {Secchi }}=1.5 \mathrm{~m}$ both the euphotic depth $\left(z_{e u}=5.02 \mathrm{~m}\right)$ and maximum colonization depth for macrophytes $\left(z_{\text {macrophytes }}=3.82 \mathrm{~m}\right)$ would exceed the mean lake depth of $2.5 \mathrm{~m}$ in Alte Donau. On a calm day, we further could expect the optimum depth for phytoplankton growth at $2.3 \mathrm{~m}\left(z_{\text {peak-phyto }}=2.31 \mathrm{~m}\right)$.

While annual averages of Secchi disk transparency increased rather gradually throughout the years (Figure 2), individual measurements within the 27-year study period (1993-2019) varied strongly (Figure 3). Secchi depth was lowest at highly eutrophic to hypertrophic conditions with TP concentrations above 40 and $60 \mu \mathrm{mol} \mathrm{L^{-1 }}$ (Figure 3). Such nutrientrich situation corresponded to concentrations of Chl- $a$ above 24-35 $\mu \mathrm{g} \mathrm{L}^{-1}$. The period of nutrient enrichment associated with algal blooms was observed for the years 1993-1994, before 


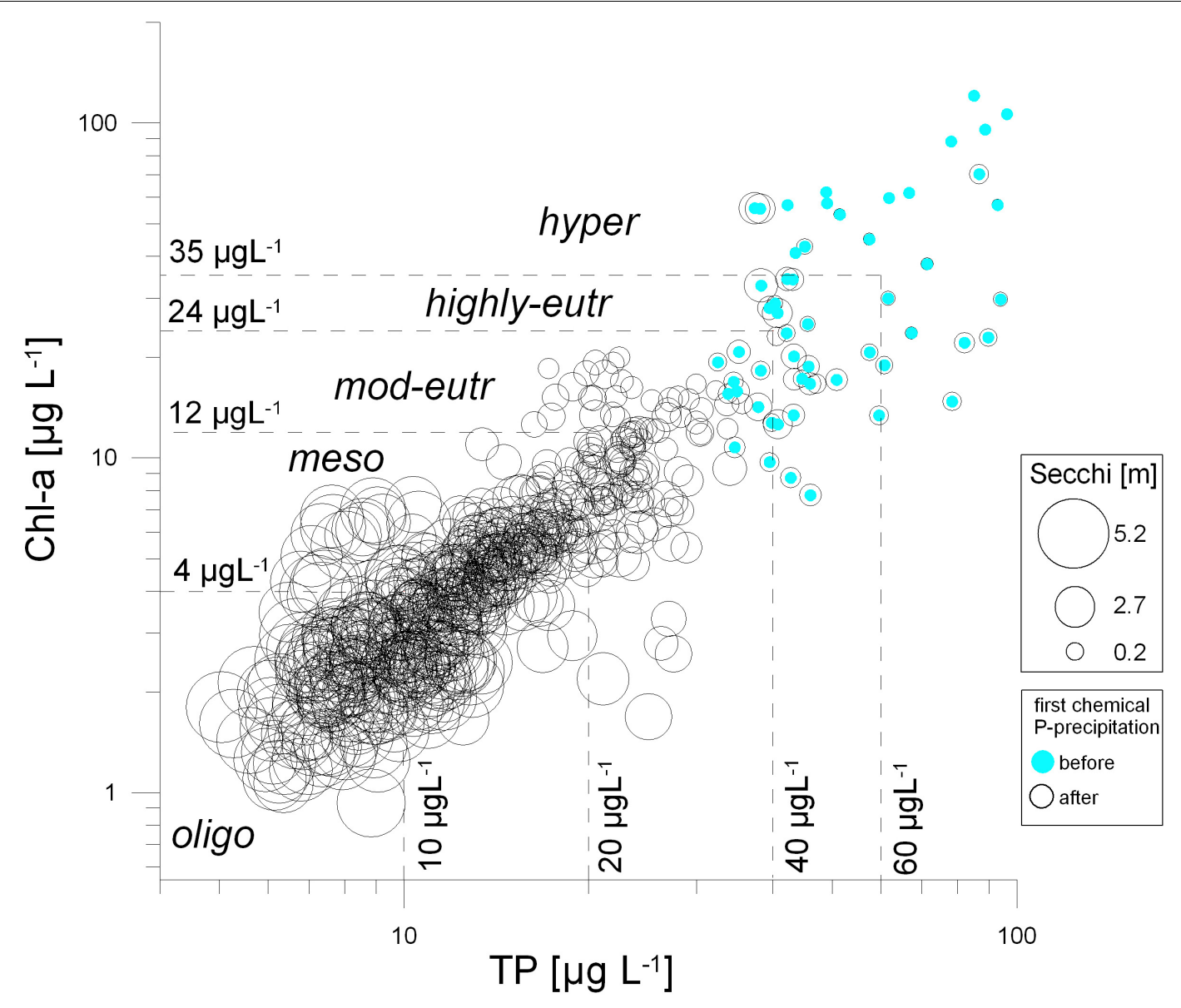

FIGURE 3 | Total phosphorus concentration (TP) versus algal biomass represented as Chlorophyll-a (Chl-a). The size of the circles indicates the Secchi disk transparency [m] ranging between 0.26 and $5.23 \mathrm{~m}$. The scatter plot is based on biweekly data from 1993 to 2019, blue points indicate the nutrient-rich period before phosphate precipitation started, from January 1993 to April 1995.
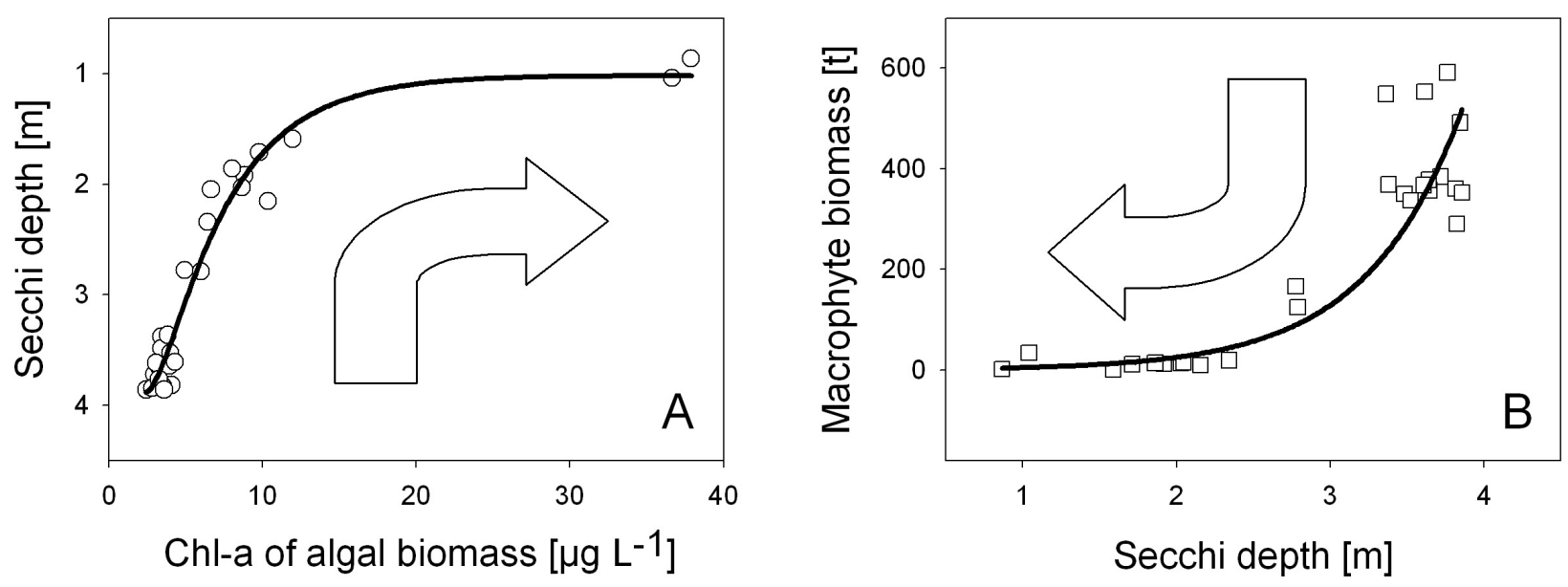

FIGURE 4 | The two sides of the same coin - the ecological perspectives of water transparency on photosynthetic organisms: Water transparency (A) as response function of phytoplankton biomass, where water turbidity decreases in the course of increasing algal biomass (measured as Chlorophyll-a in $\mu \mathrm{g} \mathrm{L}^{-1}$ ) and (B) as light utilization factor controlling the growth of underwater macrophytes biomass as dry weight in $t$ for the whole lake (B). Water transparency is indicated by Secchi depth. Annual data from 1993 to 2019 (A) and 1993 to 2018 (B). 

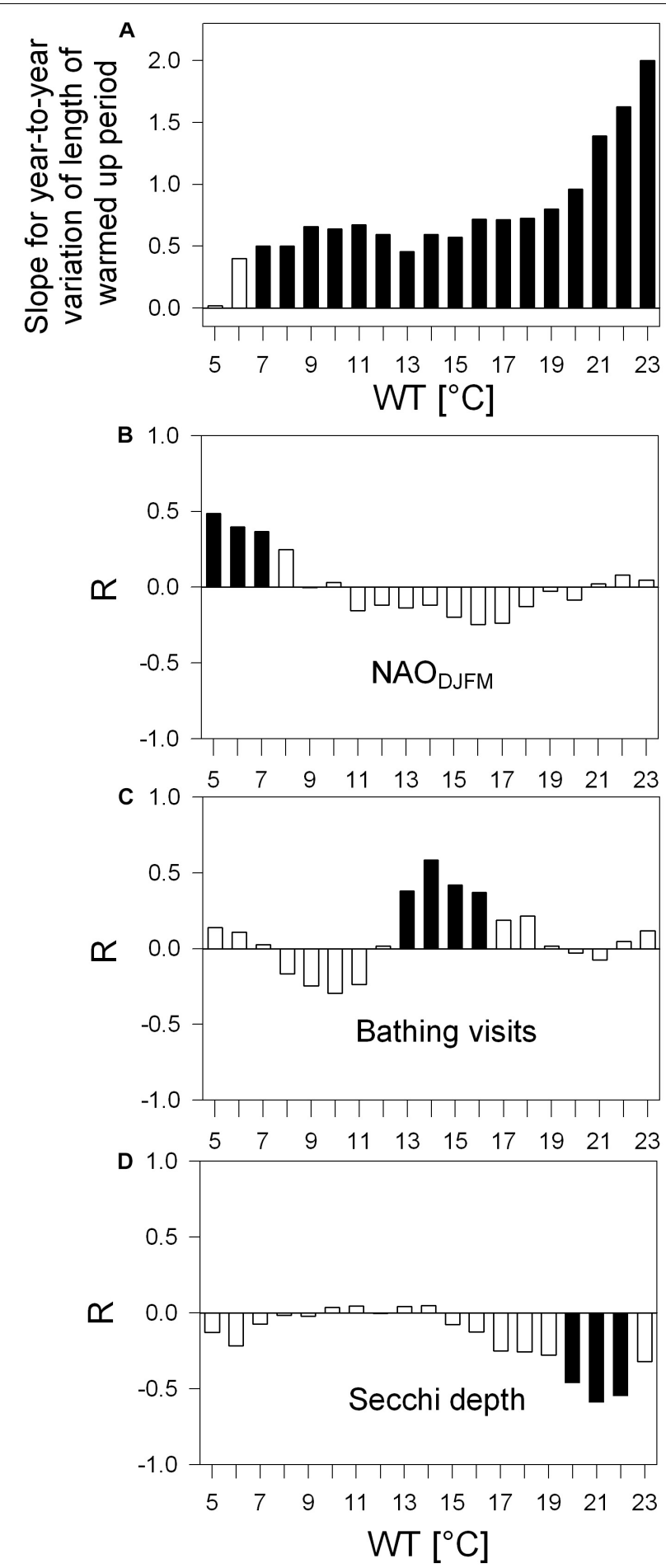

FIGURE 5 | Water surface temperature (WT) varying year-to-year, their trends (A, slopes) and relation to other parameters (B-D), Pearson correlation coefficient R. (A) Bar-chart: Slopes of lengthening of periods above certain WT values, covering 33-year development above 19 discrete WT values ranging from $5^{\circ} \mathrm{C}$ to $23^{\circ} \mathrm{C}$; all slopes are from robust trend lines proven to be statistically significant with $p<0.05$ with the only exceptions for the WTs $5^{\circ} \mathrm{C}$ and $6^{\circ} \mathrm{C}$, as indicated by white bars. For lengthening given in number of days see Table 3. (B-D) Correlograms: Correlation between detrended year-to-year

(Continued)
FIGURE 5 | Continued

variation of the length of periods (above WTs $5^{\circ} \mathrm{C}$ to $23^{\circ} \mathrm{C}$ ) and of

$\mathrm{NAO}_{D J F M}$-index (B), of detrended bathing visits per population (C, original bathing visits displayed in Figure 2) and of detrended Secchi depth (D). Black

columns indicate statistically significant Pearson correlations with $p<0.05$.

Examples of most significant $R$-values in panels (B-D) are displayed in scatter plots (Figures 7A-C).

the lake restoration started. On the contrary, high values of Secchi disk transparency were associated with low concentrations of TP and of Chl- $a$. This situation of high water clarity mirrors the success of sustained restoration of Alte Donau, which consisted of phosphate precipitation in the planktonic zone in 1995 and 1996, followed by the sustained re-establishment of underwater macrophytes (timetable of restoration measures see Table 1; RIPLOX-treatment of phosphate precipitation see Donabaum and Dokulil, 2018; Macrophyte and reed-belt re-establishment see Pall, 2018; Pall and Goldschmid, 2018; for sustained fish management see Waidbacher and Silke-Silvia Drexler, 2018).

The two sides of ecological perspectives for water transparency are shown in Figure 4 and refer to data from 1993 onward in Alte Donau. With an increase in phytoplankton corresponding to an increase in Chl- $a$ concentrations up to about $10 \mu \mathrm{g} \mathrm{L}^{-1}$, the Secchi depth linearly decrease (Figure 4A). Further increase of phytoplankton density, which potentially contributes to selfshading by algae, leads to approaching a minimum Secchi depth of $1 \mathrm{~m}(1.02 \mathrm{~m}$ and $0.86 \mathrm{~m})$, the lowest annual mean values of Secchi disk transparency in the open water body measured in Alte Donau. In turn, water transparency stimulates growth of underwater macrophytes (Figure 4B). Massive exponential growth, which leads to establishing an underwater macrophyte biomass of about $300 \mathrm{t}$ and more (macrophytes in dry weight of the whole lake area), is observed in Alte Donau when annual Secchi depth is $3.5 \mathrm{~m}$ or even higher (Figure $4 \mathbf{B}$ ).

This annual mean threshold of $3.5 \mathrm{~m}$ Secchi disk transparency was exceeded first from autumn to winter in 2001.

In following years of successful re-establishment of submerged macrophytes (mainly angiospermic species as Myriophyllum spicatum) with more than $300 \mathrm{t}$ biomass yield in the whole lake per year, i.e., 2004-2019, water transparency was on average higher than $3.5 \mathrm{~m}$ for more than the half year (average 189 day a year, $52 \%$ days a year, range: $13-75 \%$ ). Considering only the first half of the year, Secchi disk transparency was on average exceeding a depth of $3.5 \mathrm{~m}$ on 115 days (63\% days a half year, range: $23-75 \%$, January-June). Referring to spring, it was 66 days (on average $71 \%$ days in springtime, range $23-92 \%$, March to May). During mesotrophic state before eutrophication of Alte Donau, when dense charophyte meadows were observed (791 t per lake per year) which were co-occurring with cyprinid fish assemblages, the median Secchi disk transparency measured in June was $3.41 \mathrm{~m}$ (Löffler, 1988). Re-assessing this Secchi disk transparency from the late 80ies, the values for 2004 to 2019 were on average 199 days a year (54\% of days a year), 122 days the first half of the year (67\% of days from January to June), and 70 days in spring (76\% of days from March to May). The mean Secchi disk transparency was $3.5 \mathrm{~m}$ in June from 2004 


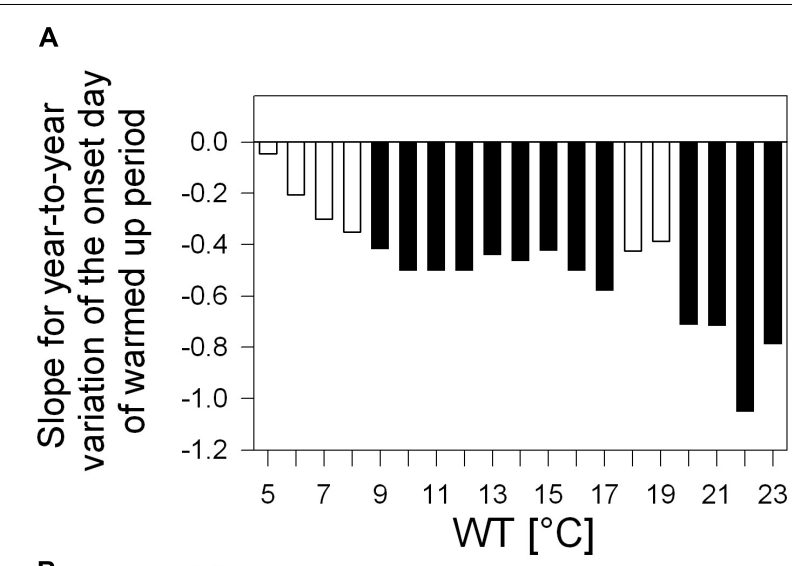

B

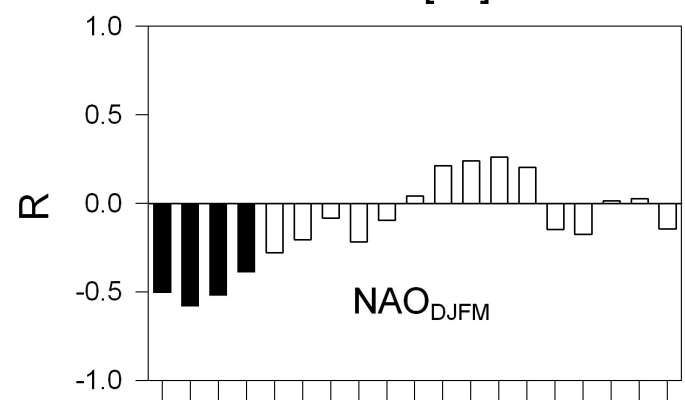

C

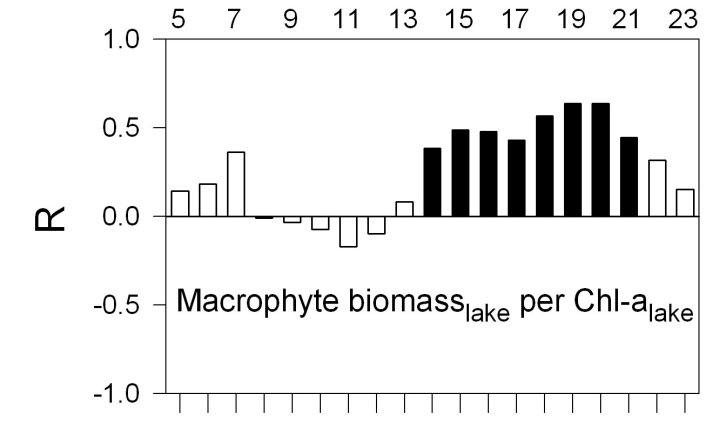

D

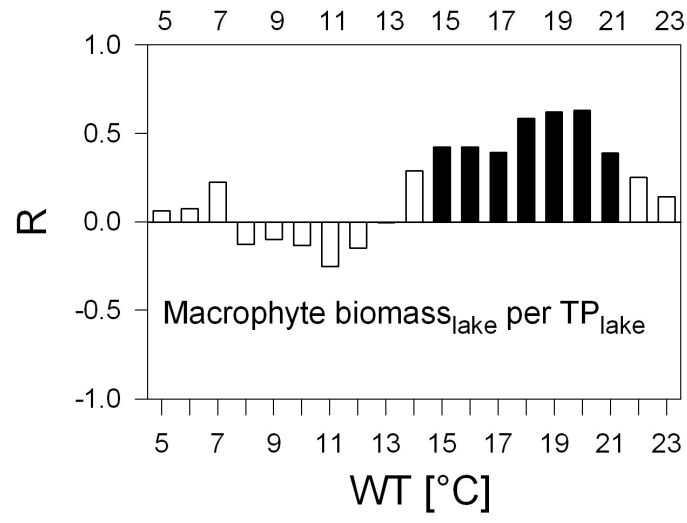

FIGURE 6 | Same as for Figure $\mathbf{5}$ with (A) as bar-chart and (B-D) as correlograms, but in panel (A) with slopes for the first day above a WT values from $5^{\circ} \mathrm{C}$ to $23^{\circ} \mathrm{C}$ (JD of the onset). (B-D) Correlograms for Pearson correlation between detrended year-to-year variation of JD onset shown in panel (A) and the $\mathrm{NAO}_{D_{J J M}}$-index (B), detrended ratio of macrophyte biomass (per lake) to Chl-a (per lake, $\mathbf{C}$ ) and detrended ratio of macrophyte biomass (per lake) to TP (per lake, D). Black columns indicate $p<0.05$. Examples of most significant $R$-values in panels (B-D) are displayed in scatter plots (Figures 7D-F); JD, Julian day. to 2019 (range: $2.5-4.5 \mathrm{~m}$ ). Thus, water transparency during both mesotrophic states, i.e., in the late 80ies (Löffler, 1988) and after chemical restoration 2004 to 2019 (Pall, 2018; Pall and Goldschmid, 2018) agree so far, but the composition and yield of macrophyte assemblage differed a lot, as it was twice the yield (1) and instead of dense stands of angiospermic species a meadow of charophytes (2) in the late 80ies.

Optical water properties in Table 2 are described for various ranges of Secchi disk transparency $\left(z_{\text {Secchi }}\right)$ and underwater light attenuation $\left(k_{P A R}\right)$. The percentage of surface ambient light at Secchi depth $\left(I_{Z_{S e c h i}}\right)$ for individual measurements $(n=131)$ ranges from $7 \%$ to $43 \%$. The mean $z_{\text {Secchi }}$ of $1.62 \mathrm{~m}$ corresponds to a visibility of $26 \%$ surface ambient light (Table $2 \mathrm{~A}$ ). $I_{Z_{\text {Sechi }}}$ is highest in summer (28\%) followed by spring (27\%) and lowest in winter (21\%) (Table 2B). $I_{Z_{\text {Secchi }}}$ also increases with trophic state, is lowest under oligotrophic (1\%) and highest under eutrophic (28\%) conditions (Table 2C).

The factors used for multiplying $z_{\text {Secchi }}$ to retrieve euphotic depth $\left(z_{e u}\right)$, maximum macrophyte colonization depth ( $\left.z_{\text {macrophytes }}\right)$ and depth of the epilimnetic peak of phytoplankton biomass $\left(z_{\text {peak-phyto }}\right)$ vary over a wide range during the seven-year study (see methods). For individual measurements $(n=131), z_{e u}$ exceeds $z_{\text {Secchi }}$ by a factor $\left(f_{e u}\right)$ varying between 1.77 and 5.45 (mean 3.45, Table 2A). Analogous, concerning $z_{\text {macrophytes }}$ and $z_{\text {peak-phyto }}$, the factors $f_{\text {macrophytes }}$ and $f_{\text {peak-phyto }}$ vary between $1.35-4.15$ (mean 2.63, Table 2A) and $0.81-$ 2.51 (mean 1.59, Table 2A) for exceeding $z_{\text {Secchi }}$, respectively. Seasonal mean values of these three factors, displaying the ratio or soundness between Secchi disk readings and underwater light attenuation measurements, do not vary stochastically but follow a pattern with highest means in summer and lowest means in winter (Table 2B). When categorizing water transparency measurements according to the trophic classification scheme (Table 2C), the mean values of these factors increase with trophy, i.e., are lowest for the oligotrophic and highest for eutrophic state. The variation of these factors thus relies on phytoplankton biomass, which was simultaneously measured during this investigation: relatively small ratios between a depth of $1 \%, 3 \%$, and $12 \%$ of surface ambient light to Secchi disk readings, i.e., high values of the factors $f_{e u}, f_{\text {macrophytes }}$, and $f_{\text {peak-phyto }}$, were observed when phytoplankton biomass was low (low mean Chl- $a$ for winter and for oligotrophic state, see Table 2). In turn, largest factors were found when phytoplankton was high, i.e., during peak season in summer and under eutrophic conditions.

The $z_{\text {Secchi }}$ of $3.5 \mathrm{~m}$ is derived as a critical threshold for macrophyte growth (Figure 4). It refers to $z_{e u}=12 \mathrm{~m}$ and $z_{\text {macrophytes }}=9.1 \mathrm{~m}$, exceeding both the maximum depths of water basins (for mesotrophic state $f_{e u}=3.42$; $f_{\text {macrophytes }}=2.6$, Table $2 \mathrm{C}$ ). Further, the corresponding depth for $z_{\text {peak-phyto }}=5.5 \mathrm{~m}$ exceeds by far the mean depth of $2.5 \mathrm{~m}$ $\left(f_{\text {peak-phyto }}=1.58\right.$, Table $\left.2 B\right)$.

Global warming is issued in Figures 5-8, focusing on trends of year-to-year variation of water surface temperature (WT) in correspondence to the NAO climate signal. In addition, the response of long-term development of WT on bathing visits, Secchi disk transparency and macrophyte development is depicted. 

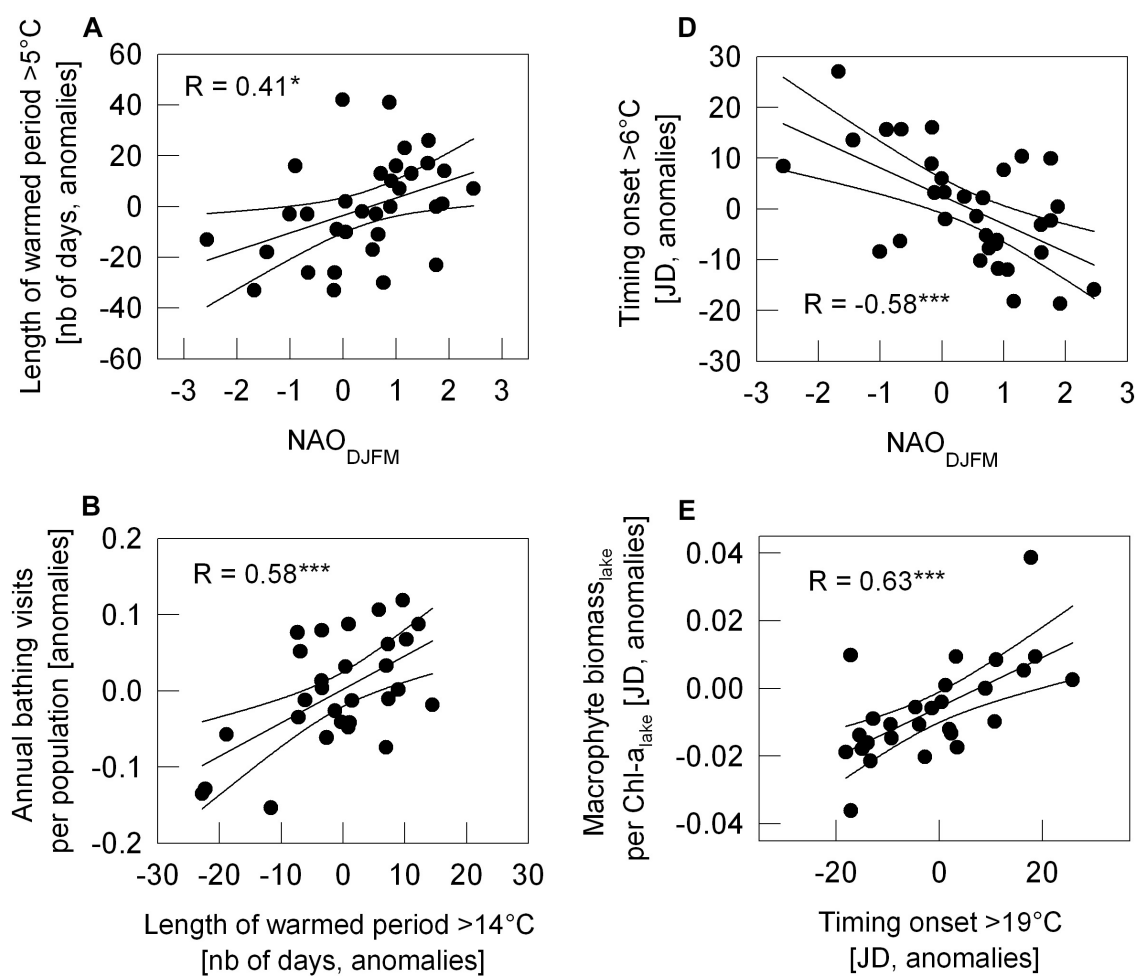

[JD, anomalies]
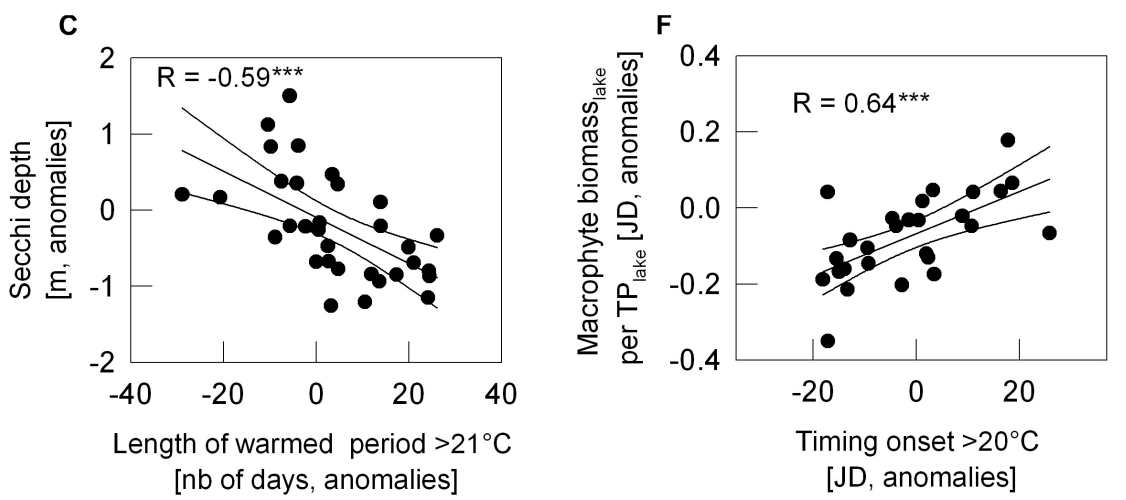

FIGURE 7 | Relation between year-to-year variation of the length of warm period number of days, (A-C) or of the onset of warming period (JD, Julian day; D-F) and year-to-year variation of NAO climate signal or further parameters indicating ecosystem status as scatter plots. $\mathrm{NAO}_{D J F M}$ against the length of warmed period above $5^{\circ} \mathrm{C}$ in panel (A) and the onset $>6^{\circ} \mathrm{C}$ in panel (D). Length period $>14^{\circ} \mathrm{C}$ against annual bathing visits per population in Vienna (B); Length of period $>21^{\circ} \mathrm{C}$ against mean Secchi depth during bathing season June-August (C); First day a year with WT $>19^{\circ} \mathrm{C}$ against the ratio of macrophyte biomass (per lake) to Chl-a (per lake) (E); First day a year with WT $>20^{\circ} \mathrm{C}$ against the ratio of macrophyte biomass (per lake) to TP (F). With exception of NAO, all data as anomalies (see section "Materials and Methods"). R for Pearson correlation coefficient, significance of correlation is marked by ${ }^{\star} p<0.05$ and ${ }^{\star \star \star} p<0.001$.

The number of days above a certain WT value was used to analyze the length of the warm period for each year (Figure 5). Within the range of warmed water above $5^{\circ} \mathrm{C}$ to $23^{\circ} \mathrm{C}$, a positive trend was found with the exception of WT of $5^{\circ} \mathrm{C}$. The trends were statistically significant for the range of WTs from $7^{\circ} \mathrm{C}$ to $23^{\circ} \mathrm{C}$ and thus verify warming of surface water for 247 to 243 days per year along the 33 -year study. Up to a WT of $19^{\circ} \mathrm{C}$, the slope gradually increased (Figure 5A), indicating a modest lengthening of the warming period of about 4 to 7 days per decade (Table 3). With a WT value of $20^{\circ} \mathrm{C}$ and further of $21^{\circ} \mathrm{C}, 22^{\circ} \mathrm{C}$, and $23^{\circ} \mathrm{C}$, the slope increased more progressively (Figure 5A), mirroring the prolongation of the warm water period above these four values by $9,12,15$, or 18 days per decade (Table 3). While in year 1987 half of the year was above $11^{\circ} \mathrm{C}$ (184 days), in year 2019 half of the year was above $13^{\circ} \mathrm{C}$ (183 days, Table 3 ). The detrended year-to-year variation of warm water above WTs $5^{\circ} \mathrm{C}, 6^{\circ} \mathrm{C}$, and $7^{\circ} \mathrm{C}$ relates significantly to the year-to-year variation of the North Atlantic Oscillation climate index for winter $\left(\mathrm{NAO}_{D J F M}\right)$ (Figure 5B). The correlograms further show mainly the significant positive coincidence between year-to-year variation of the lengthening of warmed period above $13^{\circ} \mathrm{C}-16^{\circ} \mathrm{C}$ and of the annual variation 

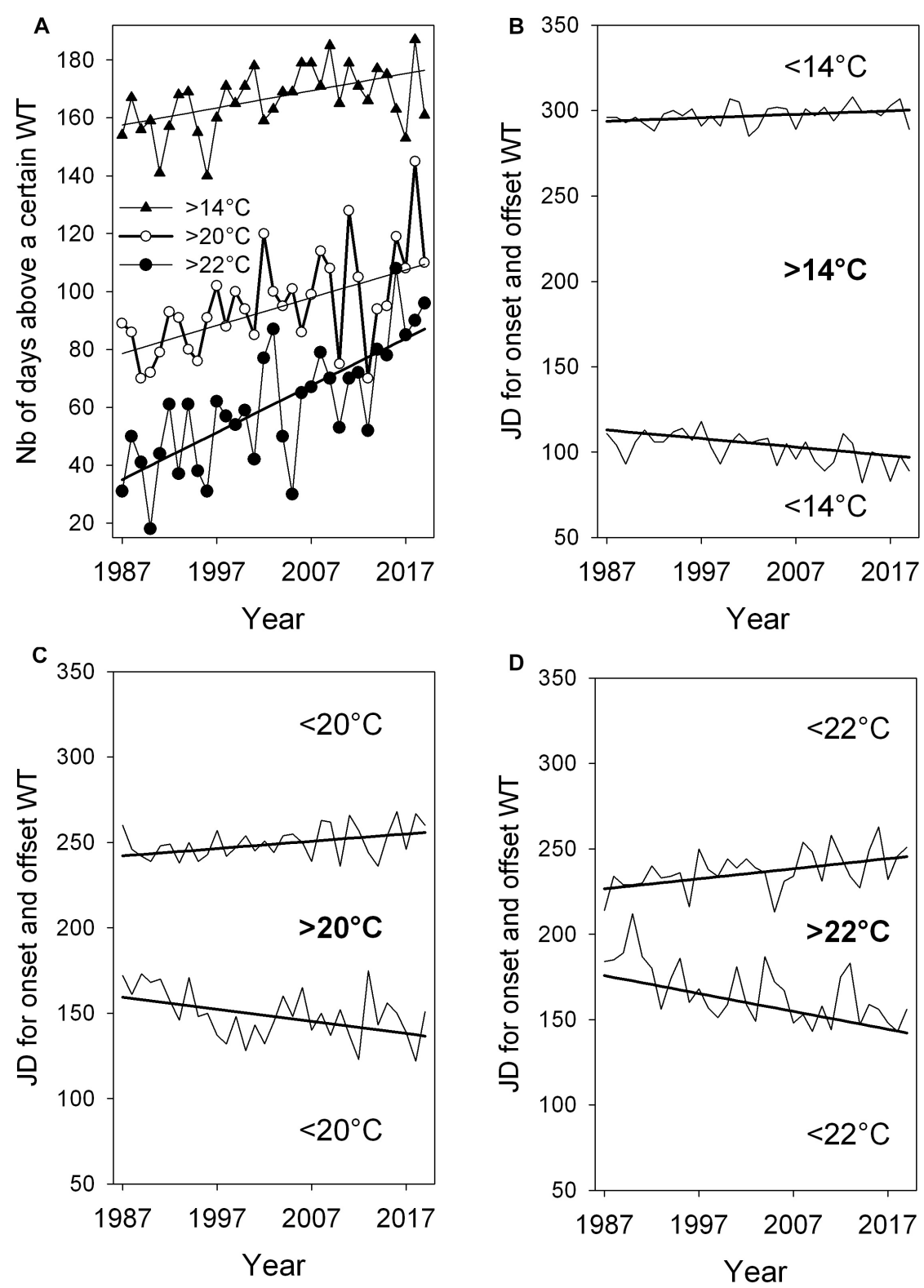

FIGURE 8 | Lengthening of the warm period above three WT values indicated by significant positive slopes of trends with $+0.59^{\star \star *}$ for $\mathrm{WT}>14^{\circ} \mathrm{C},+0.96^{\star \star \star}$ for WT $>20^{\circ} \mathrm{C}$ and $+1.63^{\star \star \star}$ for WT $>22^{\circ} \mathrm{C}$ (A). Days of onsets and offsets of the three WTs in panels (B-D). The negative trend slope for onset days in mid spring or early summer is $-0.46^{\star \star *}$ for $\mathrm{WT}>14^{\circ} \mathrm{C},-0.71^{\star}$ for $\mathrm{WT}>20^{\circ} \mathrm{C}$, and $-1.05^{\star \star *}$ for $\mathrm{WT}>22^{\circ} \mathrm{C}$. Slope for the offset in late summer or autumn is $+0.2^{\star}$ for $\mathrm{WT}<14^{\circ} \mathrm{C}$, $+0.43^{*}$ for $\mathrm{WT}>20^{\circ} \mathrm{C}$ and $+0.59^{*}$ for $\mathrm{WT}<22^{\circ} \mathrm{C}$. Significance of robust slopes with ${ }^{*} p<0.05$, ${ }^{* *} p<0.01$, and ${ }^{* \star *} p<0.001$, Year-to-year time series from 1993 to 2019. The number of days for lengthening period and time shift for onset days above $11^{\circ} \mathrm{C}, 14^{\circ} \mathrm{C}$, and $22^{\circ} \mathrm{C}$ see Table 3 .

of bathing visits per population (Figure 5C). A prolonged warm period above $20^{\circ} \mathrm{C}, 21^{\circ} \mathrm{C}$, and $22^{\circ} \mathrm{C}$ refers to lowered mean Secchi disk transparency for the bathing season (Figure 5D) (with the exception of the NAO-index, all time series data in Figures 5BD were linearly detrended prior to correlation analysis, see "Materials and Methods").

According to robust slopes in Figure 6A, the first day passing the different WT values tends to occur progressively earlier. The earlier warming is statistically significant for onsets of $9^{\circ} \mathrm{C}$ to $17^{\circ} \mathrm{C}$ and $20^{\circ} \mathrm{C}$ to $23^{\circ} \mathrm{C}$ during the 33 -year study. Intra annual earlier warming onsets above $5^{\circ} \mathrm{C}$ to $8^{\circ} \mathrm{C}$ coincide inversely with annual variation of winter $\mathrm{NAO}$ index (Figure 6B). Further, the first day above a WT value from $14^{\circ} \mathrm{C}$ to $21^{\circ} \mathrm{C}$ and $15^{\circ} \mathrm{C}$ to $21^{\circ} \mathrm{C}$ (timing of the onset days see Table 3: from Julian day 108 in mid-April to JD 164 in mid-June) corresponds significantly to the macrophyte biomass increase relative to Chl$a$ and TP, respectively (Figures 6C, D) (with the exception of the NAO-index, all time series for the onset in Figures 6BD were linearly detrended prior to correlation analysis, see "Materials and Methods"). 
Most significant relationships from Figures 5, 6 are displayed in scatter plots in Figure 7. NAO positive years coincide with years of an extended warm phase above $5^{\circ} \mathrm{C}$ (Figure 7A) and reaching earlier the temperature above $6^{\circ} \mathrm{C}$ (Figure 7D). In turn, NAO negative years refer to years with a shortened period above $5^{\circ} \mathrm{C}$ and delayed onset of water temperature above $4^{\circ} \mathrm{C}$. With a prolongation of the warm period above $14^{\circ} \mathrm{C}$, the number of bathing visits per population increases (Figure 7B). The prolongation of warm period above summer WTs, such as $21^{\circ} \mathrm{C}$ shown in Figure 7C, relates most significantly to lowered Secchi depth averaged over the bathing season. With an earlier onset of warming phase above $19^{\circ} \mathrm{C}$ and $20^{\circ} \mathrm{C}$, macrophyte biomass increases significantly relative to Chl- $a$ or TP in the lake (Figures 7E,F) and thus seem to trigger high water transparency. Steep warming trends during extreme hot summer (WT $22^{\circ} \mathrm{C}$ and $23^{\circ} \mathrm{C}$ ), however, neither seem significantly to favor further macrophyte increase relative to Chl- $a$ or TP nor to enhance further water transparency in Alte Donau (Figures 5, 6).

The time series and robust trend lines for the length of annual warm period above WTs of $14^{\circ} \mathrm{C}, 20^{\circ} \mathrm{C}$, and $22^{\circ} \mathrm{C}$, including temporal shifts of the onset and offset of these warm periods are shown in Figure 8. When comparing WTs above $14^{\circ} \mathrm{C}, 20^{\circ} \mathrm{C}$, and $22^{\circ} \mathrm{C}$, a progressive lengthening of the warm period, indicated by slopes of robust trends, is found from $14^{\circ} \mathrm{C}$ to $22^{\circ} \mathrm{C}$ (Figure 8A and Table 3). The lengthening of the annual warm period is mainly due to a pronounced earlier onset of warm period above $14^{\circ} \mathrm{C}, 20^{\circ} \mathrm{C}$ and $22^{\circ} \mathrm{C}$ in spring and early summer, rather than to a moderate delay of cooling in late summer and autumn (Figures 8B-D).

\section{DISCUSSION}

The restoration of degraded urban ecosystems, as it could be exemplified here for Alte Donau, can increase the quantity of ecosystem services per capita in densely populated areas. With the successfully restoration of Alte Donau (Dokulil et al., 2018), this urban oxbow lake became a life-enriching natural asset in Vienna again. Sustained restoration was meant to meet the goal of "maintaining the valuable water ecosystem features and excellent local recreation opportunities" as stated in Hozang (2017). Water clarity captures great attention as the most relevant socio-ecological indicator for the former floodplain riverine system that is now integrated into modern city life, as it can provide condensed information on: (1) the potential for recreational use of urban blue-green space; (2) the status of overall success of sustained restoration and ecosystem health; and (3) the ecosystem vulnerability against the superimposed global warming trend, accelerated in man-made age.

\section{Water Clarity Attracts Recreational Values Enhancing Ecosystem Services}

According to a questionnaire survey about city lake park Alte Donau with 1023 respondents in Vienna (2015 to 2017), which faced restoration at stable conditions with sustained dense macrophyte stands, five key issues were identified (Hozang, 2017). Highest priority was perceived for water quality by local resident visitors and business owners of boat rentals, restaurants and public baths, thus underlining the water quality awareness outlined by other socio-economic studies (e.g., Michael et al., 1996; Wilson and Carpenter, 1999; Gibbs et al., 2002; Lee, 2017). Respondents in Vienna were highly satisfied with the improved water quality and thus acknowledged lake restoration in general. The Secchi disk transparency of Alte Donau at the time of the questionnaire survey in Vienna was already stabilized according to the clear-water state associated with sustained macrophytes (annual means ranged between $3.4 \mathrm{~m}$ and $3.8 \mathrm{~m}$ ). It thus exceeded by far the $1.5 \mathrm{~m}$ minimum threshold of bathing aesthetics, and also a higher Secchi disk transparency of $2.75 \mathrm{~m}$ indicated for satisfying $90 \%$ of respondents for perceiving a water clarity suitable for bathing according to questionnaire surveys by Smith et al. (1991, 1995a). Accordingly, when judging further improvement of water quality, water clarity did not represent an issue. Instead, underwater-macrophyte cutting was perceived to be important by visitors but also owners of public baths, boat rentals and restaurants with access to the lake banks, to restrict excessive biomass development of tall-growing macrophytes. Floating plant fragments on the water surface were perceived as causing nuisance (see also below target issue to replace Myriophyllum spicatum by charophytes). Secondly, $70 \%$ of the respondents considered near-natural lake banks as important elements for the preservation of selected littoral areas, although the free accessibility to the water edge for other areas had top priority. Despite the overall high priority of water clarity and presence of stable macrophyte stands, which indicates an attitude toward nature, deficits in a deeper understanding of the ecosystem Alte Donau and of ecological criteria for natural banks were striking. The other three key issues perceived as important for visiting Alte Donau were concerns about (3) bathing and boating, (4) the high recreational value of the whole area including meadows in the park, which finally (5) led to an improved quality-of-place for local residents. Around $88 \%$ of the bathing visitors of Alte Donau used public bathes (paying an admission fee for lido), the remaining visitors used public swimming areas for free. In the latter case, access to the water edge is provided through meadows or public wooden piers and platforms with bathing ladders in-between the reed belt (Hozang, 2017). Thus, the park around the lake Alte Donau, which underwent a comprehensive planning in parallel to lake restoration (Masterplan Alte Donau in Hozang, 2018), is also freely accessible as green space all year. According to the urban development plan (Mittringer et al., 2005), the greenblue infrastructure of Alte Donau contributes to the natural capital of Vienna in mainly two ways. On the one hand, the near natural lake is valued as natural asset aimed at bridging aspects of compact settlement in the city and green space of high ecological quality. On the other hand, recreational services mediated by water clarity concern also human health which are mitigated by urban heat island effects in Vienna (e.g., Roetzer et al., 2000; Matzarakis et al., 2010; Žuvela-Aloise et al., 2014). In general, spaces with high evapotranspiration (Sánchez-Carrillo et al., 2004; Gunawardena et al., 2017; Wu et al., 2019), such as the littoral reed belt of natural or near natural lakes, where annual evapotranspiration can exceed annual evaporation of the open 
lake surface (e.g., Herbst and Kappen, 1999), are most effectively improving microclimate. In this view, urban recreational services mediated by water clarity go by far beyond satisfying bathing aesthetics. Green-blue spaces in cities are thus in general higher rated by people than green spaces alone (White et al., 2010).

\section{Water Clarity in View of Sustainable Restoration Measures and Ecosystem Health}

Deterioration of freshwaters concerns ecologists worldwide. Sophisticated methods rely on biota integrity, using indicator species for assessing water quality and ecosystem health (Karr, 1991; Dokulil and Teubner, 2002; Schneider and Melzer, 2003; Padisák et al., 2006; Teubner et al., 2018b; Rücker et al., 2019). In case of eutrophication, however, i.e., when man-made surplus of nutrients is the sole relevant human impact, sustained increase of water clarity is the main target of restoration (e.g., Gulati et al., 2008). Water clarity is thus understood as "valued attribute" for judging the water quality (Håkanson et al., 2005; Peeters et al., 2009; Keeler et al., 2012). It enables a high degree of predictability of ecosystem health because it describes water quality simultaneously in view of two important aspects, i.e., the availability of nutrients pointing in the direction of potential phytoplankton development (indirect effect on water clarity) and the ambient light climate (direct effect on water clarity). Thus, water clarity mirrors the extent of nutrient surplus, that in turn triggers photosynthetic growth, yielding biomass on the one side, and the access to ambient light along the water column required for growth of primary producers, on the other side. These two aspects of water clarity are in particular relevant for shallow aquatic ecosystems, as exemplified here for the oxbow lake Alte Donau. With the reduction of the phosphorus-pool following the lake restoration, phytoplankton growth became limited and phytoplankton biomass drastically declined leading to an increase in water clarity. With the improvement of water clarity, submerged plants spontaneously grew from residual fragments (Dokulil et al., 2018). This switch between alternate stable states, represented by nutrient-rich algal-turbid state and water plant dominated clear-water state (e.g., Scheffer et al., 1993; Cristofor et al., 2003; Søndergaard et al., 2010; Hilt, 2015; Phillips et al., 2016), is well known in aquatic sciences and is seen as a cornerstone in lake restoration (e.g., Carpenter and Cottingham, 1997; Hilt et al., 2006; Søndergaard et al., 2007; Gulati et al., 2008; Jeppesen et al., 2012).

Underwater light climate is most commonly measured with Secchi depth readings (e.g., Forsberg and Ryding, 1980; Nürnberg, 1996; Giardino et al., 2001; ÖNORM M6231, 2001), but can also be determined by light attenuation along depth profiles. The latter is often used in case of "lake bottom view" (e.g., Meijer et al., 1999), i.e., Secchi disk transparency exceeds the lake depth (e.g., Löffler, 1988). The measure of underwater light attenuation further suits better for turbid water bodies where steep profiles of light attenuation are expected (e.g., Dokulil, 1975; Katalin et al., 2009). The exponential attenuation of irradiance with depth relies on light absorption and light scattering, i.e., depends mainly on the water color and on the characteristics of seston particles (e.g., Löffler, 1988; Koenings and Edmundson, 1991; Zimmermann-Timm, 2002). Secchi transparency and underwater light attenuation in our study, calculated within seasons or within boundaries of trophic classification scheme and thresholds of human perception for bathing aesthetic, mirror basically the background of a certain chlorophyll content. Whatever the factor predicting $1 \%, 3 \%$, and $12 \%$ surface ambient light or light intensity at Secchi depth was, high values were associated with high Chl- $a$. Chlorophyll- $a$ is the principal light harvesting pigment of primary producers and commonly used as rough estimator of phytoplankton biomass. Chl- $a$ accounts with $0.50 \%$ to wet weight phytoplankton biomass in Alte Donau (Teubner et al., 2018b). In addition to light absorption by phytoplankton, these biotic particles contribute to underwater light scattering (e.g., Kirk, 1975; Bricaud and Morel, 1986). As our study on Alte Donau covers four seasons over years accomplishing the lake restoration from hyper- to a meso- oligotrophic state, optical properties of this lake are as variable as found in a multi-lake study. The wide range of surface ambient light at Secchi depth in Alte Donau agrees with the variation from 0.8 to $36.3 \%$ among different lake types by Koenings and Edmundson (1991). Further, the factor $f_{e u}$ which is commonly used to predict $z_{e u}$ by $z_{\text {Sech }}$, ranged widely among seasons and boundaries of trophic states (i.e., between 3.0 and 3.8) in Alte Donau, as confirmed by other studies (Montes-Hugo et al., 2003). Compared with Alte Donau, the ratio $z_{e u} / z_{S e c c h i}$ was even higher in the shallow, mesotrophic but turbid soda Lake Neusiedl, where it ranged from 3.5 to 6.0 for individual measurements (mean: 4.6, Dokulil, 1979), and lower in the deep mesotrophic alpine Mondsee (range 1.3-4.9, mean: 2.7, $n=26$, 1999-2000, Teubner and Dokulil, unpublished data). Dokulil (1979) further reported mean ratios ranging from 1.3 to 5.0 for 26 mainly lake sites worldwide, Padial and Thomaz (2008) between 1.8 and 2.6 for subtropical reservoirs and floodplain lakes. These results underscore that Secchi disck readings need to be calibrated against exponential light attenuation in specific lakes and seasons, when they are used to predict optical properties relevant for the biota, such as the euphotic depth ( $1 \%$ of surface ambient light), the maximum colonization depth of macrophytes ( $3 \%$ of surface ambient light; cf. Middelboe and Markager, 1997; Dennison et al., 1993), and the optimum depth of epilimnetic phytoplankton growth (12\% of surface ambient light, Teubner et al., 2004).

Both photosynthetic lake assemblages, phytoplankton and macrophytes, basically require the same nutrients and light sources when sharing the same habitat. Each of them includes a bunch of organisms that often are not taxonomically linked to each other. Phytoplankton communities include eukaryotic algae and prokaryotic cyanobacteria. Besides common physiological features for photosynthetic autotrophs, some algae such as cyanobacteria and cryptophytes rely on light absorption at specific wave-lengths, which is different from most eukaryotic species. For many cyanobacteria, but also for some bacillarioand ochrophytes, mixotrophy, in addition to autotrophic photosynthesis, is an alternative or obligate pathway of nutrition. Both, structural aspects (e.g., specific pigment pattern, different ways of nutrition) and physiological strategies (e.g., coping with ambient light and nutrients by optimizing resource utilization, 
acclimation), allow a balanced phytoplankton growth along the light attenuation gradient which may also result in different phytoplankton species inhabiting different layers in the water column (Klausmeier and Litchman, 2001; Greisberger and Teubner, 2007; Salmaso and Padisák, 2007; Zohary et al., 2010; Dokulil and Teubner, 2012; Mantzouki et al., 2016). In Alte Donau, the contribution of cyanobacteria to total phytoplankton varied strongly over the 22 -year study period and was highest under nutrient rich conditions as described in detail in Teubner et al. (2018a).

Submerged macrophyte assemblages inhabiting lakes cover again taxonomically different species. They include vascular plants, charophytes (stoneworts, brittleworts) and bryophytes (Lacoul and Freedman, 2006), which exclusively rely on photosynthesis and are commonly anchored to the lake bottom. The different types of growth forms (e.g., near bottom rosettes, tall-growing with caulescent branches, canopy formations on water surface) also allow macrophytes to utilize underwater light at different layers in the water column (for inventory of about 40 macrophyte species in Alte Donau see Pall, 2018; Pall and Goldschmid, 2018).

It is common for both assemblages, phytoplankton (e.g., Wall and Briand, 1979; Kohl and Nicklisch, 1988) and submerged macrophytes (e.g., Chambers and Kalff, 1985; Dennison et al., 1993; Middelboe and Markager, 1997), that requirements for optimal growth under ambient light can vary from group to group and from species to species. Nevertheless, both assemblages often colonize mainly at certain depth layers. In the case of phytoplankton, epilimnetic community (dominated by strict photosynthetic organisms, with less mixotrophic species) avoids the near surface layer due to stress by too high light intensity (PAR and also UV radiation) and builds up maxima at $12 \%$ of surface ambient light (Teubner et al., 2004). In deep lakes, in addition to the epilimnetic peak at $12 \%$ surface light, metalimnetic phytoplankton (often in combination with mixotrophy) can develop below the euphotic zone, at 0.1 to $1 \%$ of surface ambient light (e.g., Walsby and Schanz, 2002; Zotina et al., 2003; Teubner et al., 2004; Greisberger and Teubner, 2007; Dokulil and Teubner, 2012; Yankova et al., 2016). The epilimnetic peak is most relevant for shallow lakes such as Alte Donau. An epilimnetic layer of about $10-14 \%$ of surface ambient light (12\% of surface-ambient light for lake growth optimum, Teubner et al., 2004) expands vertically the water transparency, but narrows to only few centimeters if water transparency is very low. At high water transparency, this layer of optimal growth is far from the lake surface, but is very close to the top under high turbidity. High water clarity is associated with diverse but low number of phytoplankton species (often measured by low Chl- $a$ at low TP) and often relates to an increase in biodiversity and integrity, as discussed above.

Conversely, under hypertrophic conditions that are associated with mass-development of phytoplankton, only few phytoplankton groups develop, and in particular cyanobacteria that are known for their potential of blooming and of producing toxins, thus damage ecosystem health and inhibit recreational use (Teubner et al., 1999; Chorus et al., 2000; Dokulil and Teubner, 2000; Graham et al., 2010; Mantzouki et al., 2016;
Scherer et al., 2017; Dokulil et al., 2018). Their single cells, filaments or aggregates dramatically enhance underwater light attenuation by self-shading along the whole water column. Thus, shading acclimated cyanobacteria are abundant during mixing in spring while other cyanobacteria that are protected by UV-shield can form dense scums near the surface during stratified conditions in summer. Phytoplankton assemblages dominated by cyanobacteria are commonly scarcely diverse, as only few species can survive in an extreme habitat in terms of low light and surplus of nutrients, which indicate low ecosystem integrity. Thus, in view of lake assessment by phytoplankton, water clarity indeed provides an indicator for ecosystem health.

Water clarity is also used as reference for ecosystem quality when referring to macrophytes (Van Nes et al., 2002; Nõges et al., 2003; Feldmann and Nõges, 2007; Köhler et al., 2010; Søndergaard et al., 2010). For plants, the bottleneck for successful colonization is germination. Since light commonly acts as signal to start seasonal spreading or growing (e.g., Penfield et al., 2005; Chen et al., 2008; Nelson et al., 2010), which is also relevant for macrophytes (Ozimek, 2006; Tuckett et al., 2010), early seedling development and leaf-out during spring depends on certain thresholds of light availability. With water level draw-down of $25 \mathrm{~cm}$ for only few days in March to May, the light signal for stimulating vernal growth is enhanced and thus can trigger leafout and shoot development of submerged macrophytes even in deeper layers of the littoral zone (Pall, 2018; Pall and Goldschmid, 2018). In other studies, the clear-water phase, which is referring to lake phenology and describes the period when water clarity temporarily increases to "lake bottom view" for a few days (at least in shallow lakes) due to grazing of phytoplankton by zooplankton, also seems to be important for macrophyte succession starting in spring (Van Nes et al., 2002). The timing of the clear-water phase in Alte Donau varied between the 95th (early April) and 145th day (late May) during our investigation, and tends to be observed progressively earlier in recent years due to global warming (Teubner et al., 2018b). Thus, a clear-water phase during the transition from late spring to summer might favor macrophyte growth over phytoplankton summer bloom.

A temporary increase of water clarity by vernal water-level draw-down represents the window of opportunity for sustaining macrophyte development later in the year. It was a cornerstone of macrophyte management during the period of re-establishing macrophytes in Alte Donau, carried out in four successive years, 2002-2005. After the first 2 years, with total submerged plant biomass of $20 \mathrm{t}$ (2002) and $125 \mathrm{t}$ (2003), the annual macrophyte biomass yield strongly increased to more than $350 \mathrm{t}$ afterward of sustained water clarity.

With the re-establishment of underwater vegetation, submerged macrophyte growth takes advantage against phytoplankton growth (Phillips et al., 2016), and thus clear water is stabilized by sustained macrophyte domination (Cristofor et al., 2003; Hilt et al., 2006; Hilt, 2015). The spatial tightness of habitat zonation along the depth is further relevant when considering allelopathic substances which may suppress the growth of certain species within the same assemblage, both within the phytoplankton and the macrophyte community, but can also occur also between species of algae and macrophytes 
(Van Donk and Van de Bund, 2002; Gross, 2003; Legrand et al., 2003; Berger and Schagerl, 2004; Hilt and Gross, 2008; Mulderij et al., 2009; Chang et al., 2012). Some of these studies assume that allelopathically active macrophytes contribute to stabilize sustained macrophyte growth and thus clear-water state in shallow lakes.

In our study, the threshold for Secchi disk transparency for sustained macrophyte growth in Alte Donau is at about $3.5 \mathrm{~m}$ (annual average) and thus exceeds by far the thresholds of $1.5 \mathrm{~m}$ and $2.75 \mathrm{~m}$ for bathing aesthetics (Smith et al., 1991, 1995a). The annual Secchi depth transparency of $3.5 \mathrm{~m}$ agrees with Secchi depth transparency in June 1987 by Löffler (1988) referring to the mesotrophic state in the 80ties with a dense bottom cover mainly of Chara meadows at that time. According to our study, a Secchi disk transparency of $3.5 \mathrm{~m}$ seems to satisfy minimum light requirements of macrophytes on the whole lake bottom area and is thus supporting underwater plants if no self-shading of macrophyte stands, nutrient limitation or other environmental stressors suppresses the growth of macrophytes. In addition, although macrophyte growth at dim light is possible (e.g., Nielsen and Borum, 2008), and such minimum light requirements are ecologically relevant for defining the maximum colonization depth, it is clear that optimized macrophyte yield refers to higher ambient light intensities (compare with epilimnetic phytoplankton above, with highest abundances around $12 \%$ of surface ambient light within the euphotic zone; see also average requirements of $11 \%$ for charophytes and $21 \%$ for submerged angiosperms at lowest colonization depth according to Chambers and Kalff, 1985). Assuming that macrophytes meet similar light harvesting requirements as planktonic photosynthetic biota having an optimum at a depth of $12 \%$ of surface ambient light (e.g., Teubner et al., 2004), the stratum at $5.5 \mathrm{~m}(=12 \%$ surface-light; $3.5 \mathrm{~m}$ Secchi disk transparency) might also be relevant for optimal light harvesting of submerged macrophytes in Alte Donau This optimum depth is exceeding by far the mean lake depth of $2.5 \mathrm{~m}$. The expansion of the epilimnetic layer satisfying an enhanced light requirement of $10-14 \%$ surface ambient light discussed above for phytoplankton might be relevant for the macrophytes in two ways: a settlement of near-bottom prospering macrophytes below the mean lake depth and an enhanced light availability in the water column for the spreading tall-growing macrophytes. According to other studies, light requirements of submerged macrophytes range widely from 2 to $25 \%$ (mentioned as "typical values" for freshwater species in Middelboe and Markager, 1997) or from 4 to 29\% surface light (mentioned as minimum light requirement for marine species in Dennison et al., 1993). Therefore, these results underpin that a Secchi disk transparency of $3.5 \mathrm{~m}$ satisfies light requirements of submerged macrophytes yielding in sustained large biomass in mesotrophic Alte Donau.

In 2019 , charophytes contributed almost $20 \%$ to macrophyte yield. The last step, i.e., to substitute the still abundant Myriophyllum spicatum by charophytes in Alte Donau, is thus still ongoing. M. spicatum is common in the Danube River Basin and most frequently found in habitats of fine inorganic sediment of steep bank slopes, medium velocity $(35-65 \mathrm{~cm}$ $\mathrm{s}^{-1}$ ) connected to main river channels (e.g., Janauer and Exler,
2004). In Alte Donau, dense stands of $M$. spicatum building canopy formations near the water surface were thus nuisance for recreational purposes (e.g., boating or swimming). A shift toward charophytes, which can build up meadows near the lake bottom, would stabilize best of sustained clear water state Van Donk and Van de Bund (2002) and agrees with macrophyte assemblage under mesotrophic conditions described in the 80ies in Löffler (1988). Many charophyte species are superior in nutrient poor clear freshwaters, i.e., oligotrophic state (e.g., Middelboe and Markager, 1997; Melzer, 1999). The advantage of charophyte meadows for sustained restoration effort consists in their capacity to stabilize effectively a clear-water state, as summarized by Hilt et al. (2006). Dense Charophytes stands covering the lake bottom can prevent the re-suspension of sediment particles, thus leading to nutrient-immobilization in the long-term. Further, lakes with Chara meadows benefit on their winter-green that may contribute to avoiding oxygen depletion on the sediment surface. Finally, many charophytes are heavily calcified, which ensures that fragments of charophytes sink to bottom instead of floating at the water surface, which is considered beneficial in view of recreational use. When aiming at stabilizing submerged macrophyte stands (Hilt, 2015), in particular in view of sustained growth of charophytes, a critical Secchi disk transparency of $3.5 \mathrm{~m}$ or even higher might be the target for further lake management measures in Alte Donau. A Secchi disk transparency of $1.5 \mathrm{~m}$ and $2.75 \mathrm{~m}$, which is suggested as critical values for bathing aesthetics according to Smith et al. (1991, 1995a) would be within boundaries of mesotrophic conditions, but would not be satisfactory for sustained macrophyte growth in Alte Donau in the long-term.

\section{Water Clarity for Bridging Ecosystem Health and Ecosystem Services Superimposed by Global Warming}

The Pannonian Plain, where Vienna Basin and thus Alte Donau is embedded, is seen as one of the most vulnerable region to global warming in Austria (Zweimüller et al., 2008; Dokulil and Herzig, 2009; Dokulil et al., 2010; Soja et al., 2013) and in Central Europe (Honti and Somlyody, 2009; Olesen et al., 2011; Nistor, 2019), respectively. Accordingly, the year-to-year variation of lake surface water temperature in Alte Donau responded to the climate signal, the North Atlantic Oscillation (NAO) Index. This climate index is commonly used to detect long-term variability and trends from lake physics to lake-biota driven by global warming in the Northern Hemisphere (e.g., Anneville et al., 2002; Straile et al., 2003; Blenckner et al., 2007; Dokulil and Herzig, 2009; Soja et al., 2013; Wrzesiński et al., 2015). Although the climate driven processes are controlled by large scale phenomena throughout the year, climate response to NAO is most pronounced for winter to early spring and is fading later in the year due to ecosystem filters (e.g., Blenckner et al., 2007; Dokulil et al., 2010; Ptak et al., 2018; Teubner et al., 2018a; Schmidt et al., 2019). In accordance, the climate response in Alte Donau to WT was most significant during the cold season, i.e., for the number of days with WT $>5^{\circ} \mathrm{C},>6^{\circ} \mathrm{C}$, and $>7^{\circ} \mathrm{C}$ and the yearly onset (Julian day) for stepwise passing WTs of $6^{\circ} \mathrm{C}, 7^{\circ} \mathrm{C}$, and $8^{\circ} \mathrm{C}$. 
Apart from the direct correspondence with the climate signal, seasonal lake phenology changes could be verified by significant warming trends. The lengthening of periods above a certain value of water temperature, in detail graphically exemplified for length with WT $>14^{\circ} \mathrm{C},>20^{\circ} \mathrm{C}$, and $>22^{\circ} \mathrm{C}$ in our study, were mainly due to a steep and thus significant slope toward an earlier onset passing the WTs than by weak slopes for the delayed offsets. Thus, the lengthening of growing season in Alte Donau relies primarily on an advanced onset in spring than a delayed autumnal cooling, as also described for other phenology studies (Menzel and Fabian, 1999; Chmielewski and Rötzer, 2001; Dokulil and Teubner, 2012; Garonna et al., 2016). According to spring phenology of plant flowering by Roetzer et al. (2000), the Julian day observed for urban sites in Vienna was in all cases in advance ( 3 to 5 days) to rural sites of the city. Therefore, an interference of suburban climate on surface WT might not be neglected, but such an analysis was beyond the scope of this study. The flowering phenology study, however, should increase the awareness regarding how an urban space can benefit from a natural water body in terms of improving microclimate, and vice versa to what extent the urban climate may enhance warming in urban waters.

An increase in bathing visit is associated with a lengthening of the periods that satisfy an intermediate water temperature, in the range of 13 to $16^{\circ} \mathrm{C}$, which is relevant for determining the start of recreational use in a year. Secchi disk transparency seems in particular dampened during hot summer periods with a WT from $20^{\circ} \mathrm{C}$ to $22^{\circ} \mathrm{C}$ and is not corresponding to an enhanced macrophyte yield.

The impact on water clarity, as controlled by the balance between phytoplankton or macrophytes and the total pool of the main nutrient element, i.e., phosphorus, became evident for certain summer periods during the decadal limnological survey of Alte Donau. With an advanced warming for exceeding WT from $15^{\circ} \mathrm{C}$ to $21^{\circ} \mathrm{C}$, i.e., after the transition from spring to summer when phytoplankton is passing the clear-water phase (Teubner et al., 2018a), sustained macrophyte development at the expense of phytoplankton growth or TP pool size, respectively, takes place. This supports other studies that show how macrophytes benefit from lake phenology in terms of short-term enhancement of water transparency (Van Nes et al., 2002). The same is valid for the lengthening of the warm period. Only extreme high WT above $22^{\circ} \mathrm{C}$ to $23^{\circ} \mathrm{C}$, when also Secchi depth transparency significantly decreases relative to extreme WT increase, do not result in a further increase of macrophyte biomass. The annual biomass yield of submerged plants relative to the pool of nutrient resources (as TP) and to phytoplankton (as Chl-a) benefits from elevated but not extreme WT in this water body of the temperate zone. Macrophytes thus seem to benefit from an earlier onset of temperatures between $14^{\circ} \mathrm{C}$ and $15^{\circ} \mathrm{C}$. The year-to-year variation of the day when $19^{\circ} \mathrm{C}$ or $20^{\circ} \mathrm{C}$ is reached for the first time seems to correspond best to a maximal biomass yield of macrophyte per year, when related to TP or Chl- $a$. A sustained macrophyte dominance stabilizes the clear-water state as stated before, supports ecosystem health and satisfies recreational use. In principle, many submerged macrophytes may respond with higher yields when just comparing the impact of enhanced water temperature on their growth. Myriophyllum spicatum is an angiospermic macrophyte which clearly seems to cope well with climate warming (Aiken, 1981; Patrick et al., 2012). Not in general (Choudhury et al., 2019) but also some common charophytes seem to benefit from a temperature increase (Rojo et al., 2017) as far as ephemeral ponds do not disappear due to climatic drought. To our knowledge, there is no climate response bioassay study for Myriophyllum spicatum in comparison with common Chara species as found in Alte Donau (Pall, 2018), to answer which macrophyte species would benefit the most from climate warming.

A previous study, however, showed that the prolongation of the warm season in Alte Donau - in addition to a progressively earlier clear-water phase - favors thermophilic zooplankton species in many ways. The most spectacular zooplankton species to mention here is an alien species, the freshwater jellyfish Craspedacusta sowerbii (Ciutti et al., 2017; Kozuharov et al., 2017; Trichkova et al., 2017), which builds up its medusa stage more frequently as WT exceeds $21^{\circ} \mathrm{C}$ more often in Alte Donau (Teubner et al., 2018a). Thus, despite the success of restoration measures, biotic relationships can be superimposed by climate warming and thus finally also interfering ecosystem services and ecosystem health.

\section{CONCLUSION}

In conclusion, water transparency can serve as a key indicator of multi-functional socio-ecological values to assess near natural assets of green-blue spaces and ecosystem health as exemplified for the oxbow lake Alte Donau in Vienna. Judgment of water clarity by public perception is of great importance for communicating the success of restoration or urban planning in modern cities life. In ecological terms, water transparency identifies the overall success of lake restoration or ecosystem health status if no other impacts than local nutrient surplus or global risk by climate warming pose potential threats. The critical water transparency forcing alternate nutrient allocation from planktonic algae under nutrient-rich conditions to submerged macrophytes of nutrient-limitation (details in Dokulil et al., 2018), however, exceeds requirements of water transparency that is satisfying people's awareness by littoral "lake bottom view," i.e., judging good water quality by bathing aesthetics. Our results suggest that annual Secchi transparency of $3.5 \mathrm{~m}$ or even higher is required to accomplish the still ongoing, last step of sustained lake restoration, i.e., to further the increase of charophytes above $20 \%$ macrophyte yield contribution. This step at the expense of tall-growing Myriophyllum spicatum aimed at further stabilizing the clear-water state in Alte Donau. In this view, even if water transparency can be indeed judged as reliable socio-ecological indicator, annual surveys of recreational waters should still go further beyond measuring Secchi disk transparency. A knowledge in advance, which goes beyond Secchi depth readings, contributes to mitigating the superimposed response by climate warming and other potential threatening impacts in the accelerated man-made 
age, which seem to hamper water transparency in general during extreme hot summer seasons and favor long-term thermophilic macrophytes such as Myriophyllum spicatum in particular.

\section{DATA AVAILABILITY STATEMENT}

The raw data supporting the conclusions of this article will be made available by the authors, without undue reservation.

\section{AUTHOR CONTRIBUTIONS}

KT mainly conceived the manuscript idea and did data analysis, statistics and preparation of graphs, text, and literature search and writing. IT conducted statistics, advanced data processing concerning underwater light attenuation and climate research in Tables 2-3, writing paragraphs in the "Materials and Methods," "Results," "Discussion," and "Concise Abstract". KP contributed by strong expertise in macrophyte biology and management including re-establishing of charophyte-vegetation, providing recent field data about macrophyte yield and success of charophyte plantings in the Alte Donau, co-preparation of graphs, critical review of literature about physiology, and macrophyte management. WK re-assessed measurements of underwater light conducted, refreshed by advanced methodology analyzing critical depths, contribution to text of "Materials and Methods," "Results," and "Discussion". MT contributed most to the main idea of re-emphasizing water transparency, contributed

\section{REFERENCES}

Aarup, T. (2002). Transparency of the North Sea and Baltic Sea-a Secchi depth data mining study. Oceanologia 44, 323-337.

Aiken, S. G. (1981). A conspectus of Myriophyllum (haloragaceae) in North America. Brittonia 33, 57-69. doi: 10.2307/28 06578

Angradi, T. R., Ringold, P. L., and Hall, K. (2018). Water clarity measures as indicators of recreational benefits provided by US lakes: swimming and aesthetics. Ecol. Indic. 93, 1005-1019. doi: 10.1016/j.ecolind.2018. 06.001

Anneville, O., Souissi, S., Ibanez, F., Ginot, V., Druart, J. C., and Angeli, N. (2002). Temporal mapping of phytoplankton assemblages in Lake Geneva: annual and interannual changes in their patterns of succession. Limnol. Oceanogr. 47, 1355-1366. doi: 10.4319/lo.2002.47.5.1355

Arnberger, A., and Eder, R. (2012). The influence of green space on community attachment of urban and suburban residents. Urban For. Urban Green. 11, 41-49. doi: 10.1016/j.ufug.2011.11.003

Berger, J., and Schagerl, M. (2004). Allelopathic activity of Characeae. Biol. Bratislava 59, 9-16.

Blenckner, T., Adrian, R., Livingstone, D. M., Jennings, E., Weyhenmeyer, G. A., George, D. G., et al. (2007). Large-scale climatic signatures in lakes across Europe: a meta-analysis. Glob. Change Biol. 13, 1314-1326. doi: 10.1111/j.13652486.2007.01364.x

Bolund, P., and Hunhammar, S. (1999). Ecosystem services in urban areas. Ecol. Econ. 29, 293-301.

Boyer, A. L., Comby, E., Flaminio, S., Le Lay, Y. F., and Cottet, M. (2019). The social dimensions of a river's environmental quality assessment. AMBIO 48, 409-422.

Bricaud, A., and Morel, A. (1986). Light attenuation and scattering by phytoplanktonic cells: a theoretical modeling. Appl. Opt. 25, 571-580. doi: 10.1364/ao.25.000571 to all analyses and writing about socio-limnological aspects, in particular Secchi depth and its interpretation. TO contributed with data and analysis mostly to Figure 2 and Table 1; discussion and writing about results provided by socio-economic life project at Alte Donau, green-blue spaces in Vienna, in view of city master plan and ongoing macrophyte management. MD contributed in particular to methods of optical properties; restoration perspective Alte Donau, critical contribution at all stages of manuscript preparation concerning analysis, graphical display, text, and literature search. All authors contributed to the article and approved the submitted version.

\section{FUNDING}

This study was funded and promoted in many ways by the City of Vienna, Municipal Department - 45 (Water Management).

\section{ACKNOWLEDGMENTS}

We thank Karl Donabaum and the Municipal Department 45 (Water Management - Vienna) for supporting the study and providing long-term data of Alte Donau 1993-2019. We also thank Dr. Tilo Hegewald (LTV Saxony, Germany) for valuable comments issued on water transparency in lakes. We further gratefully acknowledge the constructive criticism of two reviewers.

Bulkley, J. W., and Mathews, A. P. (1974). Water Quality Relationships in the Great Lakes: Analysis of a Survey Questionnaire. (Ann Arbor, MI: Michigan University), 1-84.

Carpenter, S. R., and Cottingham, K. L. (1997). Resilience and restoration of lakes. Conserv. Ecol. 1:2.

Chambers, P. A., and Kalff, J. (1985). Depth distribution and biomass of submersed aquatic macrophyte communities in relation to Secchi depth. Can. J. Fish. Aquat. Sci. 42, 701-709. doi: 10.1139/f85-090

Chang, X., Eigemann, F., and Hilt, S. (2012). Do macrophytes support harmful cyanobacteria? Interactions with a green alga reverse the inhibiting effects of macrophyte allelochemicals on Microcystis aeruginosa. Harmful Algae 19, 76-84. doi: 10.1016/j.hal.2012.06.002

Chen, H., Zhang, J., Neff, M. M., Hong, S. W., Zhang, H., Deng, X. W., et al. (2008). Integration of light and abscisic acid signaling during seed germination and early seedling development. Proc. Natl. Acad. Sci. U.S.A. 105, 4495-4500. doi: $10.1073 /$ pnas.0710778105

Chmielewski, F. M., and Rötzer, T. (2001). Response of tree phenology to climate change across Europe. Agric. For. Meteorol. 108, 101-112. doi: 10.1016/s01681923(01)00233-7

Chorus, I., Falconer, I. R., Salas, H. J., and Bartram, J. (2000). Health risks caused by freshwater cyanobacteria in recreational waters. J. Toxicol. Environ. Health B Crit. Rev. 3, 323-347. doi: 10.1080/109374000436364

Choudhury, M. I., Urrutia-Cordero, P., Zhang, H., Ekvall, M. K., Medeiros, L. R., and Hansson, L. A. (2019). Charophytes collapse beyond a critical warming and brownification threshold in shallow lake systems. Sci. Total Environ. 661, 148-154. doi: 10.1016/j.scitotenv.2019.01.177

Ciutti, F., Flaim, G., and Cappelletti, C. (2017). La medusa Craspedacusta sowerbii Lankester, 1880: nuova osservazione nei laghi trentini e distribuzione in Italia. Biol. Ambient. 31, 174-177.

Cristofor, S., Vadineanu, A., Sarbu, A., Postolache, C., Dobre, R., and Adamescu, M. (2003). Long-term changes of submerged macrophytes in the Lower 
Danube Wetland System. Hydrobiologia 506(1-3), 625-634. doi: 10.1023/b: hydr.0000008601.16757.35

Crutzen, P. J. (2002). Geology of mankind. Nature 415:23. doi: 10.1038/415023a

Dalby, S. (2016). Framing the anthropocene: the good, the bad and the ugly. Anthropocene Rev. 3, 33-51. doi: 10.1177/2053019615618681

Dennison, W. C., Orth, R. J., Moore, K. A., Stevenson, J. C., Carter, V., Kollar, S., et al. (1993). Assessing water quality with submersed aquatic vegetation: habitat requirements as barometers of Chesapeake Bay health. BioScience 43, 86-94.

Dokulil, M. (1975). Horizontal- und Vertikalgradienten in einem Flachsee (Neusiedlersee, Österreich)," in Verhandlungen der Gesellschaft für Ökologie Wien 1975, ed. P. Müller (Dordrecht: Springer), 177-187. doi: 10.1007/978-94015-7168-5_27

Dokulil, M. (1979). "Optical properties, colour and turbidity," in Neusiedlersee: The Limnology of a Shallow Lake in Central Europe, ed. H. Löfler (Dordrecht: Springer), 151-167. doi: 10.1007/978-94-009-9168-2_15

Dokulil, M. T., and Herzig, A. (2009). An analysis of long-term winter data on phytoplankton and zooplankton in Neusiedler See, a shallow temperate lake, Austria. Aquat. Ecol. 43, 715-772. doi: 10.1007/s10452-009-9282-3

Dokulil, M. T. and Kabas, W. (2018). "Phytoplankton Photosynthesis and Production," in The Alte Donau: Successful Restoration and Sustainable Management - An Ecosystem Case Study of a Shallow Urban Lake (Aquatic Ecology Series 10), eds M. T. Dokulil, K. Donabaum, and K. Teubner (Cham: Springer), 149-163.

Dokulil, M. T, Donabaum, K., and Teubner, K. (eds) (2018). The Alte Donau: Successful Restoration and Sustainable Management - An Ecosystem Case Study of a Shallow Urban Lake (Aquatic Ecology Series 10). Cham: Springer.

Dokulil, M., and Teubner, K. (2012). Deep living Planktothrix rubescens modulated by environmental constraints and climate forcing. Hydrobiologia 698, 29-46. doi: $10.1007 / \mathrm{s} 10750-012-1020-5$

Dokulil, M. T., and Teubner, K. (2000). Cyanobacterial dominance in lakes. Hydrobiologia 438(1-3), 1-12.

Dokulil, M. T., and Teubner, K. (2002). Assessment of ecological integrity from environmental variables in an impacted oligotrophic, Alpine lake: whole lake approach using 3D-spatial heterogeneity. Water Air Soil Pollut. Focus 2, 165180.

Dokulil, M. T., and Teubner, K. (2011). "Eutrophication and climate change: present situation and future scenarios," in Eutrophication: Causes, Consequences and Control, eds A. A. Ansari, S. Singh Gill, G. Lanza, and W. Rast (Dordrecht: Springer), 1-16. doi: 10.1007/978-90-481-9625-8_1

Dokulil, M. T., Teubner, K., Jagsch, A., Nickus, U., Adrian, R., Straile, D., et al. (2010). "The impact of climate change on lakes in Central Europe," in The Impact of Climate Change on European Lakes, (Aquatic Ecology Series 4) ed. G. George (Cham: Springer), 387-410. doi: 10.1007/978-90-481-2945-4_20

Donabaum, K., and Dokulil, M. T. (2018). "Restoration and lake management," in The Alte Donau: Successful Restoration and Sustainable Management - An Ecosystem Case Study of a Shallow Urban Lake (Aquatic Ecology Series 10), eds M. T. Dokulil, K. Donabaum, and K. Teubner (Cham: Springer), 45-54. doi: 10.1007/978-3-319-93270-5_5

Donabaum, K., and Riedler, P. (2018). "Long-Term Changes of the Physicochemical Conditions in Alte Donau," in The Alte Donau: Successful Restoration and Sustainable Management - An Ecosystem Case Study of a Shallow Urban Lake (Aquatic Ecology Series 10), eds M. T. Dokulil, K. Donabaum, and K. Teubner (Cham: Springer), 55-69. doi: 10.1007/978-3-319-93270-5_6

Dou, Y., Zhen, L., De Groot, R., Du, B., and Yu, X. (2017). Assessing the importance of cultural ecosystem services in urban areas of Beijing municipality. Ecosyst. Serv. 24, 79-90. doi: 10.1016/j.ecoser.2017.02.011

Dunn, O. J., and Clark, V. A. (1974). Applied Statistics: Analysis of Variance and Regression. (New York, NY: Wiley), 353

Feldmann, T., and Nõges, P. (2007). Factors controlling macrophyte distribution in large shallow Lake Võrtsjärv. Aquat. Bot. 87, 15-21. doi: 10.1016/j.aquabot. 2007.01.004

Forsberg, C., and Ryding, S. O. (1980). Eutrophication parameters and trophic state indices in 30 waste receiving Swedish lakes. Arch. Hydrobiol. 89, 189-207.

Funk, A., Reckendorfer, W., Kucera-Hirzinger, V., Raab, R., and Schiemer, F. (2009). Aquatic diversity in a former floodplain: remediation in an urban context. Ecol. Eng. 35, 1476-1484. doi: 10.1016/j.ecoleng.2009. 06.013
Garonna, I., de Jong, R., and Schaepman, M. E. (2016). Variability and evolution of global land surface phenology over the past three decades (1982-2012). Glob. Change Biol. 22, 1456-1468. doi: 10.1111/gcb.13168

Giardino, C., Pepe, M., Brivio, P. A., Ghezzi, P., and Zilioli, E. (2001). Detecting chlorophyll, Secchi disk depth and surface temperature in a sub-alpine lake using Landsat imagery. Sci. Total Environ. 268(1-3), 19-29. doi: 10.1016/s00489697(00)00692-6

Gibbs, J. P., Halstead, J. M., Boyle, K. J., and Huang, J. C. (2002). An hedonic analysis of the effects of lake water clarity on New Hampshire lakefront properties. Agric. Resour. Econ. Rev. 31, 39-46. doi: 10.1017/ s1068280500003464

Ginzburg, B., Chalifa, I., Gun, J., Dor, I., Hadas, O., and Lev, O. (1998). DMS formation by dimethylsulfoniopropionate route in freshwater. Environ. Sci. Technol. 32, 2130-2136. doi: 10.1021/es9709076

Graham, J. L., Loftin, K. A., Meyer, M. T., and Ziegler, A. C. (2010). Cyanotoxin mixtures and taste-and-odor compounds in cyanobacterial blooms from the Midwestern United States. Environ. Sci. Technol. 44, 7361-7368. doi: 10.1021/ es 1008938

Greisberger, S., and Teubner, K. (2007). Does pigment composition reflect phytoplankton community structure in differing temperature and light conditions in a deep alpine lake? An approach using HPLC and delayed fluorescence techniques 1. J. Phycol. 43, 1108-1119. doi: 10.1111/j.1529-8817. 2007.00404.x

Gross, E. M. (2003). Allelopathy of aquatic autotrophs. Crit. Rev. Plant Sci. 22(3-4), 313-339. doi: 10.1080/713610859

Gulati, R. D., Pires, L. M. D., and Van Donk, E. (2008). Lake restoration studies: failures, bottlenecks and prospects of new ecotechnological measures. Limnologica 38(3-4), 233-247. doi: 10.1016/j.limno.2008.05.008

Gunawardena, K. R., Wells, M. J., and Kershaw, T. (2017). Utilising green and bluespace to mitigate urban heat island intensity. Sci. Total Environ. 584, 1040-1055. doi: 10.1016/j.scitotenv.2017.01.158

Haidvogl, G. (2019). "Tod und Verderben: Verschmutztes Wasser und Krankheiten," in Wasser Stadt Wien. Eine Umweltgeschichte, ed. Zentrum für Umweltgeschichte (Wien: Universität für Bodenkultur Wien), 182-192.

Haidvogl, G., Guthyne-Horvath, M., Gierlinger, S., Hohensinner, S., and Sonnlechner, C. (2013). Urban land for a growing city at the banks of a moving river: Vienna's spread into the Danube island Unterer Werd from the late 17th to the beginning of the 20th century. Water Hist. 5, 195-217. doi: 10.1007/ s12685-013-0078-y

Håkanson, L., Blenckner, T., Bryhn, A. C., and Hellström, S. S. (2005). The influence of calcium on the chlorophyll-phosphorus relationship and lake Secchi depths. Hydrobiologia 537(1-3), 111-123. doi: 10.1007/s10750-004$2605-4$

Hein, T., Schwarz, U., Habersack, H., Nichersu, I., Preiner, S., Willby, N., et al. (2016). Current status and restoration options for floodplains along the Danube River. Sci. Total Environ. 543, 778-790. doi: 10.1016/j.scitotenv.2015.09.073

Helsel, D. R., and Hirsch, R. M. (2002). Statistical Methods in Water Resources Techniques of Water-Resources Investigations of the United States Geological Survey. Reston, VA: US Geological Survey.

Herbst, M., and Kappen, L. (1999). The ratio of transpiration versus evaporation in a reed belt as influenced by weather conditions. Aquat. Bot. 63, 113-125. doi: 10.1016/s0304-3770(98)00112-0

Hering, D., Borja, A., Carstensen, J. Carvalho, L., Elliott, M., Feld, C. K., Heiskanen, A.-S., et al. (2010). The European water framework directive at the age of 10: a critical review of the achievements with recommendations for the future. Sci. Total Environ. 408. 4007-4019. doi: 10.1016/j.scitotenv.2010.05.031

Hilt, S. (2015). Regime shifts between macrophytes and phytoplankton-concepts beyond shallow lakes, unravelling stabilizing mechanisms and practical consequences. Limnetica 34, 467-480.

Hilt, S., and Gross, E. M. (2008). Can allelopathically active submerged macrophytes stabilise clear-water states in shallow lakes? Basic Appl. Ecol. 9, 422-432. doi: 10.1016/j.baae.2007.04.003

Hilt, S., Gross, E. M., Hupfer, M., Morscheid, H., Mählmann, J., Melzer, A., et al. (2006). Restoration of submerged vegetation in shallow eutrophic lakesa guideline and state of the art in Germany. Limnologica 36, 155-171. doi: 10.1016/j.limno.2006.06.001

Hohensinner, S. (2019). "GIS Reconstruction of the Viennese Danube River Landscape 1529-2010," in Caminhos do Rio - Rios das Grandes Civilizações, 
Turres Veteras, Edições Colibri 21, ed. C. Guardado da Silva (Lisboa: Universidade de Lisboa), 115-131.

Honti, M., and Somlyody, L. (2009). Stochastic water balance simulation for Lake Balaton (Hungary) under climatic pressure. Water Sci. Technol. 59, 453-459. doi: $10.2166 /$ wst.2009.886

Hozang, B. (2017). EU-LIFE+ Urban Lake Alte Donau, Sozioökonomische Studie, Magistrat der Stadt Wien, MA45 - WIENER GEWÄSSER. Available online at: file:///C:/Users/ELCOT/Downloads/Projektpraesentation_Urban\%20LakeLife-Alsterforum_08_Juni\%202017_komp.pdf (accessed May 15, 2020).

Hozang, B. (2018). "New planning activities in vienna's water-management," in The Alte Donau: Successful Restoration and Sustainable Management - An Ecosystem Case Study of a Shallow Urban Lake (Aquatic Ecology Series 10), eds M. T. Dokulil, K. Donabaum, and K. Teubner (Cham: Springer), 355-373.

Hupfer, M., and Kleeberg A. (2007). "State and pollution of freshwater ecosystems Warning signals of a changing environment," in Climate Change: Enough Water for All?, eds J. L. Lozán, H. Grassl, P. Hupfer, L. Menzel and C.-D. Schönwiese (Hamburg: GEO), 126-132.

Hurrell, J., (2020). National Center for Atmospheric Research Staff. Last modified 09 Jan (2020). The climate data guide: Hurrell North Atlantic Oscillation (NAO) Index (station-based). Available online at: https://climatedataguide.ucar. edu/climate-data/hurrell-north-atlantic-oscillation-nao-index-station-based (accessed May 15, 2019).

Istvánovics, V., Clement, A., Somlyody, L., Specziár, A., László, G., and Padisák, J. (2007). "Updating water quality targets for shallow Lake Balaton (Hungary), recovering from eutrophication." in Eutrophication of Shallow Lakes with Special Reference to Lake Taihu, China, eds B. Qin, Z. Liu, and K. Havens (Dordrecht: Springer), 305-318. doi: 10.1007/s10750-006-0509-1

Janauer, G. A., and Exler, N. (2004). Distribution and habitat conditions of the six most frequent hydrophytes in the Danube River corridor: status 2002. Limnol. Rep. 35, 407-411.

Janecek B., Leitner P., Moog O., and Teubner K. (2018). "Effect of restoration measures on the benthic invertebrates of a Danube backwater (Alte Donau)," in The Alte Donau: Successful Restoration and Sustainable Management - An Ecosystem Case Study of a Shallow Urban Lake (Aquatic Ecology Series 10), eds M. T. Dokulil, K. Donabaum, and K. Teubner (Cham: Springer), 243-274. doi: 10.1007/978-3-319-93270-5_14

Jeppesen, E., Sondergaard, M., Sondergaard, M., and Christofferson, K. (eds). (2012). The Structuring Role of Submerged Macrophytes in Lakes, Vol. 131. Cham: Springer.

Kabas, W. (2004). Die Veränderungen der Primärproduktion in der Alten Donau in den Jahren 1995-2002. Mit einem Methodenvergleich. Ph.D. thesis, University of Vienna, Wien.

Kabisch, N. (2015). Ecosystem service implementation and governance challenges in urban green space planning-The case of Berlin, Germany. Land Use Policy 42, 557-567. doi: 10.1016/j.landusepol.2014.09.005

Karr, J. R. (1991). Biological integrity: a long-neglected aspect of water resource management. Ecol. Appl. 1, 66-84. doi: 10.2307/1941848

Katalin, V., Németh, B., and Vörös, L. (2009). Specific attenuation coefficients of optically active substances and their contribution to the underwater ultraviolet and visible light climate in shallow lakes and ponds. Hydrobiologia 632, 91-105. doi: 10.1007/s10750-009-9830-9

Kati, V., and Jari, N. (2016). Bottom-up thinking-Identifying socio-cultural values of ecosystem services in local blue-green infrastructure planning in Helsinki, Finland. Land Use Policy 50, 537-547. doi: 10.1016/j.landusepol.2015.09.031

Kazmierczak, A., and Carter, J. (2010). Adaptation to Climate Change Using Green and Blue Infrastructure: A Database of Case Studies. The University of Manchester, Manchester.

Keeler, B. L., Polasky, S., Brauman, K. A., Johnson, K. A., Finlay, J. C., O’Neill, A., et al. (2012). Linking water quality and well-being for improved assessment and valuation of ecosystem services. Proc. Natl. Acad. Sci. U.S.A. 109, 18619-18624. doi: $10.1073 /$ pnas. 1215991109

Kirk, J. T. O. (1975). A theoretical analysis of the contribution of algal cells to the attenuation of light within natural waters I. General treatment of suspensions of pigmented cells. New Phytol. 75, 11-20. doi: 10.1111/j.1469-8137.1975.tb0 1366.x

Klausmeier, C. A., and Litchman, E. (2001). Algal games: the vertical distribution of phytoplankton in poorly mixed water columns. Limnol. Oceanogr. 46, 19982007. doi: 10.4319/lo.2001.46.8.1998
Koenings, J. P., and Edmundson, J. A. (1991). Secchi disk and photometer estimates of light regimes in Alaskan lakes: effects of yellow color and turbidity. Limnol. Oceanogr. 36, 91-105. doi: 10.4319/lo.1991.36.1.0091

Kohl, J. G., and Nicklisch, A. (1988). Ökophysiologie der Algen. Berlin: AkademieVerlag.

Köhler, J., Hachoł, J., and Hilt, S. (2010). Regulation of submersed macrophyte biomass in a temperate lowland river: interactions between shading by bank vegetation, epiphyton and water turbidity. Aquat. Bot. 92, 129-136. doi: 10. 1016/j.aquabot.2009.10.018

Kozuharov, D., Kalchev, R., Beshkova, M., Stanachkova, M., Kenderov, L., Vasilev, V., et al. (2017). Occurrence of the alien freshwater jellyfish Craspedacusta sowerbii Lankester, 1880 (Cnidaria: Hydrozoa) in some Bulgarian reservoirs. Acta Zool. Bulg. 9, 67-72.

Kum, G., and Dokulil, M.T. (2018). "Morphology, Water Temperature and Climate," in The Alte Donau: Successful Restoration and Sustainable Management - An Ecosystem Case Study of a Shallow Urban Lake (Aquatic Ecology Series 10), eds M. T. Dokulil, K. Donabaum, K. Teubner (Cham: Springer), 27-34. doi: 10.1007/978-3-319-93270-5_3

Lacoul, P., and Freedman, B. (2006). Environmental influences on aquatic plants in freshwater ecosystems. Environ. Rev. 14, 89-136. doi: 10.1139/ a06-001

Lee, L. H. (2017). Appearance's aesthetic appreciation to inform water quality management of waterscapes. J. Water Resour. Prot. 9(13), 1645-1659. doi: 10.4236/jwarp.2017.913103

Legrand, C., Rengefors, K., Fistarol, G. O., and Graneli, E. (2003). Allelopathy in phytoplankton-biochemical, ecological and evolutionary aspects. Phycologia 42, 406-419. doi: 10.2216/i0031-8884-42-4-406.1

Livingstone, D. M. (2003). Impact of secular climate change on the thermal structure of a large temperate central European lake. Clim. Change 57(1-2), 205-225. doi: 10.1023/a:1022119503144

Löffler, H. (1988). Alte Donau. Limnologische Projektstudie - Ökosystem Alte Donau. Wien: Endbericht.

Mantzouki, E., Visser, P. M., Bormans, M., and Ibelings, B. W. (2016). Understanding the key ecological traits of cyanobacteria as a basis for their management and control in changing lakes. Aquat. Ecol. 50, 333-350. doi: 10.1007/s10452-015-9526-3

Matzarakis, A., Rudel, E., Zygmuntowski, M., and Koch, E. (2010). Bioclimatic maps for tourism purposes. Phys. Chem. Earth 35, 57-62. doi: 10.1016/j.pce. 2010.03.009

McLeod, A. I. (2015). Package 'Kendall'. Available online at: https://cran.r-project. org/web/packages/Kendall/Kendall.pdf

Megard, R. O., and Berman, T. (1989). Effects of algae on the Secchi transparency of the southeastern Mediterranean Sea. Limnol. Oceanogr. 34, 1640-1655. doi: 10.4319/lo.1989.34.8.1640

Meijer, M. L., de Boois, I., Scheffer, M., Portielje, R., and Hosper, H. (1999). Biomanipulation in shallow lakes in The Netherlands: an evaluation of 18 case studies. Hydrobiologia 408, 13-30. doi: 10.1007/978-94-017-2986-4_2

Melzer, A. (1999). "Aquatic macrophytes as tools for lake management," in The Ecological Bases for Lake and Reservoir Management eds D. M. Harper, B. Brierley, A. J. D. Ferguson, and G. Phillips (Dordrecht: Springer), 181-190.

Menzel, A., and Fabian, P. (1999). Growing season extended in Europe. Nature 397:659. doi: $10.1038 / 17709$

Michael, H. J., Boyle, K. J., and Bouchard, R. (1996). Water Quality Affects Property Prices: A Case Study of Selected Maine Lakes, Vol. 39. Orono, ME: University of Maine.

Middelboe, A. L., and Markager, S. (1997). Depth limits and minimum light requirements of freshwater macrophytes. Freshw. Biol. 37, 553-568. doi: 10. 1046/j.1365-2427.1997.00183.x

Mittringer, K., Schremmer, C., Krajasits, C., Glotter, K., Asadi, S., Domany, B., et al. (2005). STEP 05-Stadtentwicklungsplan Wien 2005. Available online at: https://www.wien.gv.at/stadtentwicklung/strategien/step/step05/download/ pdf/step05kurz-dt.pdf (accessed June 16, 2020).

Montes-Hugo, M. A., Alvarez-Borrego, S., and Giles-Guzmán, A. D. (2003). Horizontal sighting range and Secchi depth as estimators of underwater PAR attenuation in a coastal lagoon. Estuaries 26, 1302-1309. doi: 10.1007/ bf02803632

Mulderij, G., Mau, B., de Senerpont Domis, L. N., Smolders, A. J. P., and Van Donk, E. (2009). Interaction between the macrophyte Stratiotes aloides and 
filamentous algae: Does it indicate allelopathy? Aquat. Ecol. 43, 305-312. doi: 10.1007/s10452-008-9194-7

Naselli-Flores, L. (2008). "Urban lakes: ecosystems at risk, worthy of the best care, in Proceedings of the Taal2007: The 12th World Lake Conference, Jaipur, 1333-1337.

Nelson, D. C., Flematti, G. R., Riseborough, J. A., Ghisalberti, E. L., Dixon, K. W., and Smith, S. M. (2010). Karrikins enhance light responses during germination and seedling development in Arabidopsis thaliana. Proc. Natl. Acad. Sci. U.S.A. 107, 7095-7100. doi: 10.1073/pnas.09116 35107

Nielsen, L. T., and Borum, J. (2008). Why the free floating macrophyte Stratiotes aloides mainly grows in highly $\mathrm{CO} 2$-supersaturated waters. Aquat. Bot. 89, 379-384. doi: 10.1016/j.aquabot.2008.04.008

Nistor, M. M. (2019). Vulnerability of groundwater resources under climate change in the Pannonian basin. Geo Spat. Inf. Sci. 22, 345-358. doi: 10.1080/10095020. 2019.1613776

Nõges, P., Tuvikene, L., Feldmann, T., Tõnno, I., Künnap, H., Luup, H., et al. (2003). The role of charophytes in increasing water transparency: a case study of two shallow lakes in Estonia. Hydrobiologia 506, 567-573. doi: 10.1023/b: hydr.0000008625.36438.75

Nürnberg G. K. (1996). Trophic State of Clear and Colored, Soft- and Hardwater Lakes with Special Consideration of Nutrients, Anoxia, Phytoplankton and Fish. Lake Reserv. Manage. 12, 432-447. doi: 10.1080/074381496093 54283

Olesen, J. E., Trnka, M., Kersebaum, K. C., Skjelvåg, A. O., Seguin, B., PeltonenSainio, P., et al. (2011). Impacts and adaptation of European crop production systems to climate change. Eur. J. Agron. 34, 96-112.

ÖNORM M6231 (2001). Richtlinie für die Ökologische Untersuchung und Bewertung von Stehenden Gewässern. (Wien: Österreichisches Normungsinstitut), 58

Ozimek, T. (2006). "The possibility of submerged macrophyte recovery from a propagule bank in the eutrophic Lake Mikołajskie (North Poland)," in Macrophytes in Aquatic Ecosystems: From Biology to Management, eds J. M. Caffrey, A. Dutartre, J. Haury, K. J. Murphy, and P. M. Wade (Dordrecht: Springer), 127-131. doi: 10.1007/978-1-4020-5390-0_18

Padial, A. A., and Thomaz, S. M. (2008). Prediction of the light attenuation coefficient through the Secchi disk depth: empirical modeling in two large Neotropical ecosystems. Limnology 9, 143-151. doi: 10.1007/s10201-0080246-4

Padisák, J., Borics, G., Grigorszky, I., and Soroczki-Pinter, E. (2006). Use of phytoplankton assemblages for monitoring ecological status of lakes within the Water Framework Directive: the assemblage index. Hydrobiologia 553, 1-14. doi: 10.1007/s10750-005-1393-9

Paerl, H. W., Fulton, R. S., Moisander, P. H., and Dyble, J. (2001). Harmful freshwater algal blooms, with an emphasis on cyanobacteria. Sci. World J. 1, 76-113. doi: 10.1100/tsw.2001.16

Pall, K. (2018). "Wax and Wane of Macrophytes," in The Alte Donau: Successful Restoration and Sustainable Management - An Ecosystem Case Study of a Shallow Urban Lake, (Aquatic Ecology Series 10), eds M. T. Dokulil, K. Donabaum, and K. Teubner (Cham: Springer), 89-107. doi: 10.1007/978-3-319-93270-5_8

Pall, K., and Goldschmid, U. (2018). "Restoration of the Littoral Zone," in The Alte Donau: Successful Restoration and Sustainable Management - An Ecosystem Case Study of a Shallow Urban Lake (Aquatic Ecology Series 10), eds M. T. Dokulil, K. Donabaum, and K. Teubner (Cham: Springer), 337-354. doi: 10.1007/9783-319-93270-5_18

Patrick, D. A., Boudreau, N., Bozic, Z., Carpenter, G. S., Langdon, D. M., LeMay, S. R., et al. (2012). Effects of climate change on late-season growth and survival of native and non-native species of watermilfoil (Myriophyllum spp.): implications for invasive potential and ecosystem change. Aquat. Bot. 103, 83-88 doi: 10.1016/j.aquabot.2012.06.008

Peeters, E. T., Franken, R. J., Jeppesen, E., Moss, B., Bécares, E., Hansson, L.-A., et al. (2009). Assessing ecological quality of shallow lakes: Does knowledge of transparency suffice? Basic Appl. Ecol. 10, 89-96. doi: 10.1016/j.baae.2007.12. 009

Penfield, S., Josse, E. M., Kannangara, R., Gilday, A. D., Halliday, K. J., and Graham, I. A. (2005). Cold and light control seed germination through the bHLH transcription factor SPATULA. Curr. Biol. 15, 1998-2006. doi: 10.1016/j.cub. 2005.11.010
Phillips, G., Willby, N., and Moss, B. (2016). Submerged macrophyte decline in shallow lakes: What have we learnt in the last forty years? Aquat. Bot. 135, 37-45. doi: 10.1016/j.aquabot.2016.04.004

Preiner, S., Weigelhofer, G., Funk A., Hohensinner, S., Reckendorfer, W., Schiemer, F., et al. (2018). Danube Floodplain Lobau," in Riverine Ecosystem Management (Aquatic Ecology Series 9), eds S. Schmutz, and J. Sendzimir (Cham: Springer), 491-506. doi: 10.1007/978-3-319-73250-3_25

Ptak, M., Tomczyk, A. M., and Wrzesiński, D. (2018). Effect of teleconnection patterns on changes in water temperature in Polish lakes. Atmosphere 9:66. doi: $10.3390 /$ atmos 9020066

Roetzer, T., Wittenzeller, M., Haeckel, H., and Nekovar, J. (2000). Phenology in central Europe-differences and trends of spring phenophases in urban and rural areas. Int. J. Biometeorol. 44, 60-66. doi: 10.1007/s004840000062

Rojo, C., Carramiñana, M., Cócera, D., Roberts, G. P., Puche, E., Calero, S., et al. (2017). Different responses of coexisting Chara species to foreseeable Mediterranean temperature and salinity increases. Aquat. Bot. 138, 53-63.

Rücker, J., Nixdorf, B., Quiel, K., and Grüneberg, B. (2019). North German lowland lakes miss ecological water quality standards-A lake type specific analysis. Water 11:2547.

Salmaso, N., and Padisák, J. (2007). Morpho-functional groups and phytoplankton development in two deep lakes (Lake Garda, Italy and Lake Stechlin, Germany). Hydrobiologia 578, 97-112.

Sánchez-Carrillo, S., Angeler, D. G., Sánchez-Andrés, R., Alvarez-Cobelas, M., and Garatuza-Payán, J. (2004). Evapotranspiration in semi-arid wetlands: relationships between inundation and the macrophyte-cover: open-water ratio. Advan. Water Resour. 27, 643-655.

Sanon, S., Hein, T., Douven, W., and Winkler, P. (2012). Quantifying ecosystem service trade-offs: the case of an urban floodplain in Vienna, Austria. J. Environ. Manage. 111, 159-172.

Sapna, S., Gray, D. K., Read, J. S., O’Reilly, C. M., Schneider, P., Qudrat, A., et al. (2015). A global database of lake surface temperatures collected by in situ and satellite methods from 1985-2009. Sci. Data 2:150008

Scheffer, M., Hosper, S. H., Meijer, M. L., Moss, B., and Jeppesen, E. (1993). Alternative equilibria in shallow lakes. Trends Ecol. Evol. 8, 275-279.

Scherer, P. I., Millard, A. D., Miller, A., Schoen, R., Raeder, U., Geist, J., et al. (2017). Temporal dynamics of the microbial community composition with a focus on toxic cyanobacteria and toxin presence during harmful algal blooms in two South German Lakes. Front. Microbiol. 8:2387. doi: 10.3389/fmicb.2017.02387

Schmidt, D. F., Grise, K. M., and Pace, M. L. (2019). High-frequency climate oscillations drive ice-off variability for Northern Hemisphere lakes and rivers. Clim. Change 152, 517-532.

Schneider, S., and Melzer, A. (2003). The Trophic Index of Macrophytes (TIM)-a new tool for indicating the trophic state of running waters. Int. Rev. Hydrobiol. $88,49-67$.

Secchi, A. (1866). "Esperimente per determinare la transparenza del mare," in Sul Moto Ondoso del Mare e su le Correnti di esso Specialmente su Quelle Littorali, ed. A. Ciadi (Rome), 258-288.

Smith, D. G., Cragg, A. M., and Croker, G. F. (1991). Water clarity criteria for bathing waters based on user perception. J. Environ. Manage. 33, 285-299.

Smith, D. G., Croker, G. F., and McFarlane, K. (1995a). Human perception of water appearance: 1 . Clarity and colour for bathing and aesthetics. N. Z. J. Mar. Freshw. Res. 29, 29-43.

Smith, D. G., Croker, G. F., and McFarlane, K. (1995b). Human perception of water appearance: 2. Colour judgment, and the influence of perceptual set on perceived water suitability for use. N. Z. J. Mar. Freshw. Res. 29, 45-50.

Soja, G., Züger, J., Knoflacher, M., Kinner, P., and Soja, A. M. (2013). Climate impacts on water balance of a shallow steppe lake in Eastern Austria (Lake Neusiedl). J. Hydrol. 480, 115-124.

Søndergaard, M., Jeppesen, E., Lauridsen, T. L., Skov, C., Van Nes, E. H., Roijackers, R., et al. (2007). Lake restoration: successes, failures and long-term effects. J. Appl. Ecol. 44, 1095-1105.

Søndergaard, M., Johansson, L. S., Lauridsen, T. L., Jørgensen, T. B., Liboriussen, L., and Jeppesen, E. (2010). Submerged macrophytes as indicators of the ecological quality of lakes. Freshw. Biol. 55, 893-908.

Steffen, W., Grinevald, J., Crutzen, P., and McNeill, J. (2011). The Anthropocene: conceptual and historical perspectives. Philos. Trans. A Math. Phys. Eng. Sci. $369,842-867$. 
Straile D., Livingstone D. M., Weyhenmeyer G. A., George D. G. (2003). "The response of freshwater ecosystems to climate variability associated with the North Atlantic Oscillation," in The North Atlantic Oscillation. Climatic Significance and Environmental Impact, eds H. Hurrell, Y. Kushnir, and M. Visbeck (Washington, DC: American Geophysical Union), 263-279.

Tajima, K. (2012). "Voting with their Feet: Satisfaction and Preferences of Quality of Life in Forty Districts in Tokyo, Japan," in Living on the Boundaries: Urban Marginality in National and International Contexts, ed. C. C. Yeakey (London: Emerald Group Publishing Limited), 535-562.

Täuscher, L. (2015). 200 bzw. 150 Jahre Bestimmung der Sichttiefe - die gewässerökologischen Pionierarbeiten des estischen Kapitäns Otto von Kotzebue (1787-1846) im Jahr 1815 und des italienischen Jesuiten, Physikers und Astronomen Pietro Angelo Secchi (1818-1878) im Jahr 1865 in Bericht vom 19. Feldberger Sommerworkshop für Umweltanalytik und Umweltchemie am Krüselinsee, eds G. Kubsch, W. M. Richter, and L. Täuscher (Berlin: Humboldt-Universität zu Berlin), 27-30.

Teubner, K., Morscheid, H., Tolotti, M., Greisberger, S., Morscheid, H., and Kucklentz, V. (2004). Bedingungen für Auftreten Toxinbildender Blaualgen (Cyanobakterien) in bayerischen Seen und anderen stehenden Gewässern. (München: Bayerisches Landesamt für Wasserwirtschaft), 1-105.

Teubner, K., Feyerabend, R., Henning, H., Nicklisch, A., Woitke, P., and Kohl, J.G. (1999). Alternative blooming of Aphanizomenon flos-aquae or Planktothrix agardhii induced by the timing of the critical nitrogen-phosphorus-ratio in hypertrophic riverine lakes. Arch. Hydrobiol. 54, 325-344.

Teubner, K., Großschartner, M., and Teubner, I. E. (2018a). "Response of zooplankton to restoration and climate warming in Alte Donau," in The Alte Donau: Successful Restoration and Sustainable Management - An Ecosystem Case Study of a Shallow Urban Lake (Aquatic Ecology Series 10), eds M. T. Dokulil, K. Donabaum, and K. Teubner (Cham: Springer), 163-212.

Teubner, K., Kabas, W., and Teubner, I. E. (2018b). "Phytoplankton in Alte Donau: response to trophic change from hypertrophic to mesotrophic over 22 years," in The Alte Donau: Successful Restoration and Sustainable Management - An Ecosystem Case Study of a Shallow Urban Lake (Aquatic Ecology Series 10), eds M. T. Dokulil, K. Donabaum, and K. Teubner (Cham: Springer), 107-147.

Theil, H. (1950). A rank-invariant method of linear and polynomial regression analysis, 1, 2, and 3: Ned. Akad. Wentsch Proc. 53, 386-392, 521-525, and 1397-1412.

Tockner, K., and Schiemer, F. (1997). Ecological aspects of the restoration strategy for a river-floodplain system on the Danube River in Austria. Glob. Ecol. Biogeogr. Lett. 6, 321-329.

Tolotti, M. (2001). Phytoplankton and littoral epilithic diatoms in high mountain lakes of the Adamello-Brenta Regional Park (Trentino, Italy) and their relation to trophic status and acidification risk. J. Limnol. 60, 171-188.

Tolotti, M., and Cantonati, M. (2000). Temporal and vertical variations of chlorophyll concentrations in high mountain lakes of the Adamello-Brenta Regional Park (Trentino, Italy). Int. Vereinigung Theor. Angew. Limnol. 27, 521-526.

Trichkova, T., Vladimirov, V., Tomov, P., and Todorov. (eds) (2017). ATJIAC на инвазивните чужди видове от значение за Европейския съюз (In Bulgarian, Atlas of Invasive Alien Species of Importance to the European Union), ИБЕИ- БАН. Bulgaria: IBER-ВАS.

Tuckett, R. E., Merritt, D. J., Hay, F. R., Hopper, S. D., and Dixon, K. W. (2010). Dormancy, germination and seed bank storage: a study in support of ex situ conservation of macrophytes of southwest Australian temporary pools. Freshw. Biol. 55, 1118-1129

Van Donk, E., and Van de Bund, W. J. (2002). Impact of submerged macrophytes including charophytes on phyto-and zooplankton communities: allelopathy versus other mechanisms. Aquat. Bot. 72, 261-274.

Van Nes, E. H., Scheffer, M., Van den Berg, M. S., and Coops, H. (2002). Dominance of charophytes in eutrophic shallow lakes-when should we expect it to be an alternative stable state? Aquat. Bot. 72, 275-296.

Vincent, W. F., and Bertola, C. (2012). François Alphonse FOREL. Arch. Sci. 65, 51-64.

Völker, S., and Kistemann, T. (2011). The impact of blue space on human health and well-being-Salutogenetic health effects of inland surface waters: a review. Int. J. Hyg. Environ. Health 214, 449-460.

Vollenweider, R. A. (1968). Die wissenschaftlichen Grundlagen der Seenund Fließgewässer-eutrophierung unter besonderer Berücksichtigung des Phosphors und des Stickstoffs als Eutrophierungsfaktoren. OECD, DAS/CSI/68.27.

Waidbacher, H., and Silke-Silvia Drexler S.-S. (2018). "Fish Assemblages of the 'Alte Donau' System: communities Under Various Pressures," in The Alte Donau: Successful Restoration and Sustainable Management - An Ecosystem Case Study of a Shallow Urban Lake (Aquatic Ecology Series 10), eds M. T. Dokulil, K.Donabaum, and K.Teubner (Cham: Springer), 275-313.

Wall, D., and Briand, F. (1979). Response of lake phytoplankton communities to in situ manipulations of light intensity and colour. J. Plankton Res. 1, 103-112.

Walsby, A. E., and Schanz, F. (2002). Light-dependent growth rate determines changes in the population of Planktothrix rubescens over the annual cycle in Lake Zürich, Switzerland. New Phytol. 154, 671-687.

West, A. O., Nolan, J. M., and Scott, J. T. (2016). Optical water quality and human perceptions: a synthesis. Wiley Interdiscip. Rev. Water 3, 167-180.

White, M., Smith, A., Humphryes, K., Pahl, S., Snelling, D., and Depledge, M. (2010). Blue space: the importance of water for preference, affect, and restorativeness ratings of natural and built scenes. J. Environ. Psychol. 30, 482-493.

Wilson, M. A., and Carpenter, S. R. (1999). Economic valuation of freshwater ecosystem services in the United States: 1971-1997. Ecol. Appl. 9, 772-783.

Wrzesiński, D., Choiński, A., and Ptak, M. (2015). Effect of the North Atlantic Oscillation on the thermal characteristics of lakes in Poland. Acta Geophys. 63, 863-883.

Wu, C., Li, J., Wang, C., Song, C., Chen, Y., Finka, M., et al. (2019). Understanding the relationship between urban blue infrastructure and land surface temperature. Sci. Total Environ. 694:133742.

Yankova, Y., Villiger, J., Pernthaler, J., Schanz, F., and Posch, T. (2016). Prolongation, deepening and warming of the metalimnion change habitat conditions of the harmful filamentous cyanobacterium Planktothrix rubescens in a prealpine lake. Hydrobiologia 776, 125-138.

Yigitcanlar, T., O'Connor, K., and Westerman, C. (2008). The making of knowledge cities: Melbourne's knowledge-based urban development experience. Cities 25, 63-72.

ZAMG and Jahrbuch (2020). Available online at: https://www.zamg.ac.at/cms/de/ klima/klimauebersichten/jahrbuch, Vienna, 2020 (accessed March 12, 2020).

Zimmermann-Timm, H. (2002). Characteristics, dynamics and importance of aggregates in rivers-an invited review. Int. Rev. Hydrobiol. 87, 197-240.

Zimmermann-Timm H., and Teubner K. (2019). Stadt und Land, Gewässer im Wandel, " in Die Städte Warnsignal Klima, eds J. Lozán, S.-W. Breckle, H. Graßl, W. Kuttler, and A. Matzarakis (Hamburg: GEO), 174-181.

Zohary, T., Padisák, J., and Naselli-Flores, L. (2010). Phytoplankton in the physical environment: beyond nutrients, at the end, there is some light. Hydrobiologia $639,261-269$.

Zotina, T., Köster, O., and Jüttner, F. (2003). Photoheterotrophy and lightdependent uptake of organic and organic nitrogenous compounds by Planktothrix rubescens under low irradiance. Freshw. Biol. $48,1859-1872$.

Žuvela-Aloise, M., Koch, R., Neureiter, A., Böhm, R., and Buchholz, S. (2014). Reconstructing urban climate of Vienna based on historical maps dating to the early instrumental period. Urban Clim. 10, 490-508.

Zweimüller, I., Zessner, M., and Hein, T. (2008). Effects of climate change on nitrate loads in a large river: the Austrian Danube as example. Hydrol. Process. 22, 1022-1036.

\section{Conflict of Interest: KP is CEO of the Systema GmbH.}

The remaining authors declare that the research was conducted in the absence of any commercial or financial relationships that could be construed as a potential conflict of interest.

Copyright (๑ 2020 Teubner, Teubner, Pall, Kabas, Tolotti, Ofenböck and Dokulil. This is an open-access article distributed under the terms of the Creative Commons Attribution License (CC BY). The use, distribution or reproduction in other forums is permitted, provided the original author(s) and the copyright owner(s) are credited and that the original publication in this journal is cited, in accordance with accepted academic practice. No use, distribution or reproduction is permitted which does not comply with these terms. 